\title{
Vertebrate footprints from the Agha Jari Formation (late Miocene-Pliocene), Zagros Mountains, and a review of the Cenozoic vertebrate ichnites in the Persian Gulf region
}

\author{
Nasralloh Abbassi \& Hooshang Dashtban
}

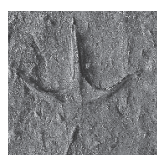

\begin{abstract}
Numerous vertebrate footprints have been found in the Konar Takhteh area (north Bushehr, north Persian Gulf) in the Agha Jari Formation. Mammal footprints are attributed to artiodactyls and have been assigned to Pecoripeda gazella. Avian footprints have been assigned to Koreanaornis hamanensis, and Persiavipes gulfi ichnogen. nov. and ichnosp. nov. Koreanaornis hamanensis has small tetradactyl footprints with slender digit imprints. Persiavipes gulfi has tetradactyl, semipalmate footprints, with distinctive, short interdigital webbing in the three anterior digits. Its backward rim is round, and the digit I imprint is well developed. In addition to the Konar Takhteh tracksite, there are other six tracksites in the Persian Gulf area, from Paleogene and Neogene deposits in Iran, Iraq, Oman, and UAE. These footprints have been attributed to large proboscideans, medium to small artiodactyls and very large to small shore birds. The ichnodiversity from northern regions of the Persian Gulf is higher than from the southern parts. In the same way, the ichnodiversity increases from the interior realm of the Arabian Peninsula to Central Iran, because there are no data about Cenozoic vertebrate ichnites in interior parts of Arabian Peninsula. Ichnodiversity in Central Iran, however, includes 24 ichnotaxa, and it may show higher biodiversity in the central Iranian Plateau relative to adjacent areas. • Key words: footprints, mammal, bird, Cenozoic, Zagros Mountains, Persian Gulf.
\end{abstract}

Abbassi, N. \& Dashtban, H. 2021. Vertebrate footprints from the Agha Jari Formation (late Miocene-Pliocene), Zagros Mountains, and a review of the Cenozoic vertebrate ichnites in the Persian Gulf region. Bulletin of Geosciences 96(2), 159-179 (11 figures, 6 tables). Czech Geological Survey, Prague. ISSN 1214-1119. Manuscript received August 1, 2020; accepted in revised form February 1, 2021; published online February 28, 2021; issued April 11, 2021.

Nasralloh Abbassi, Department of Geology, Faculty of Science, University of Zanjan, Zanjan, 38791-45371, Iran; abbasi@znu.ac.ir・Hooshang Dashtban, Exploration Directorate, National Iranian Oil Company, Khodami St, Seoul St, Tehran, 19948-14695, Iran

Vertebrate ichnology of the Cenozoic non-marine sediments of the Iranian and Arabian plates is important for the reconstruction of terrestrial vertebrate distribution in the Afro-Eurasian continents after the subduction of NeoTethys. A part of this importance is related to Cenozoic vertebrate migrations between Afro-Eurasian territories via the Iranian corridor (Hopkins 1959, Steininger et al. 1985, Tchernov 1992, Vrba 1992). The Iranian land bridge, however, may have been limited by natural barriers such as the Zagros Mountains, resulting in endemic realms for some species in Central Iran and the Persian Gulf region. Contrary to the body fossils, vertebrate footprints are autochthonous documents, and new data from Cenozoic vertebrate tracks from Persian Gulf region are an important aid for paleobiogeographic studies of the Middle East. In this context, the aim of this study is twofold: 1) to report a new vertebrate tracksite from the Persian Gulf region and, 2) to evaluate Cenozoic mammal and bird ichnodiversity in the Middle East. The new footprints described in this contribution are from the Agha Jari Formation (late Miocene-Pliocene) in the northwest of Konar Takhteh, Bandar-e Bushehr area, northern Persian Gulf (Fig. 1).

\section{Geological setting and historical background}

The Persian Gulf is an epicontinental margin basin surrounded by the Zagros Mountains, which form the active margin in the north and the Arabian stable foreland in the south (Purser \& Seibold 1973). The oil-bearing Zagros Mountains are northwest-southeast-trending from northern Iraq to southeast Iran and have been interpreted as the active zone of the Arabia-Eurasia collision belt (Stöcklin 1968, Alavi 2004, Allen et al. 2006). The tectonic history of the Zagros Mountains consists of three stages, so that the stable platform stage of the southern margin of the PaleoTethys Ocean (early Cambrian to Permian) and Jurassic 


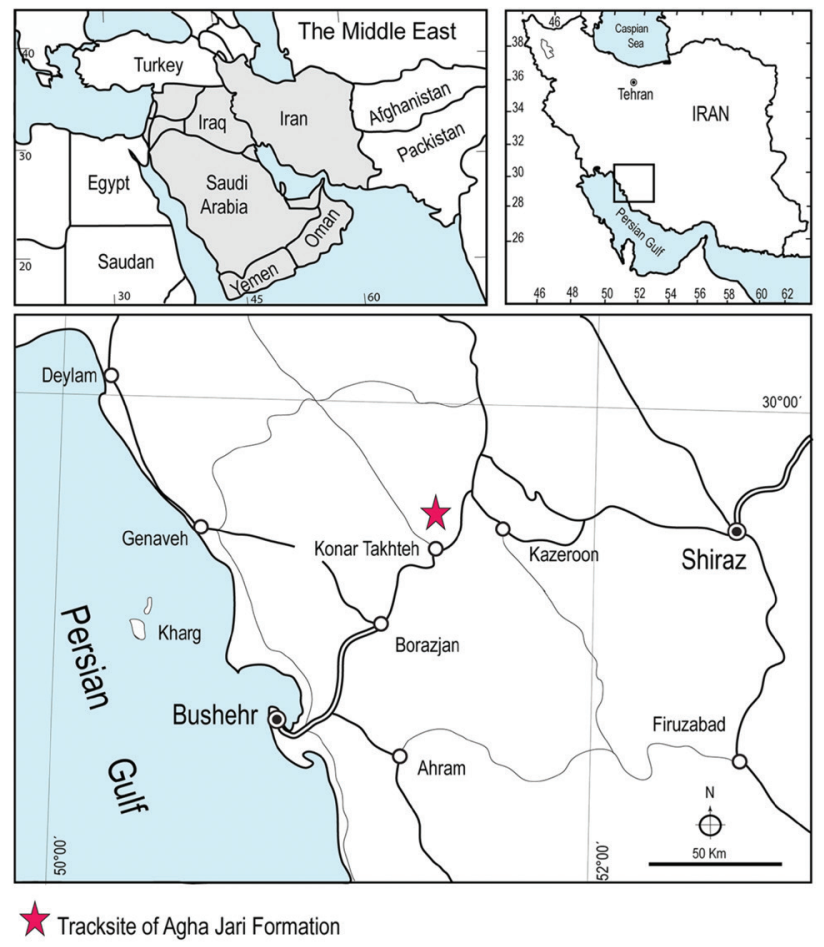

Figure 1. Location map of the track site of Konar Takhteh.

passive continental margin stage represent the first two stages (Stöcklin 1977, Koop \& Stoneley 1982, Motiei 1993, Alavi 2004, Sepehr \& Cosgrove 2004, Sherkati \& Letouzey 2004, Agard et al. 2005, Mohajjel \& Fergusson 2014). The final stage of Cretaceous-Recent subduction to collision basin, however, includes subsidence of the basin of Zagros accompanied by thick sedimentation during the Cretaceous and subduction of the Neo-Tethys that led to Arabian-Iranian collision (Motiei 1993, Aghanabati 2004, Alavi 2004). This stage was ended by a post-collision transgressive sequence of the Fars Group (the Gachsaran, Mishan, Agha Jari and Bakhtyari formations) during the Miocene to Pliocene, and the Zagros Basin migrated to its present position in the Persian Gulf region (Koop \& Stoneley 1982, Alavi 2004). The Fars Group includes sedimentary rocks that were deposited in supratidal and sabkha environments at the base (Gachsaran Formation), marine carbonate and marl (Mishan Formation), sedimentary rocks of the coastal plain and meandering rivers (Agha Jari Formation) and, finally, conglomerate formed in a braided river environment (Bakhtyari Formation). Cenozoic rocks of the Zagros Mountains in north Iraq comprise sedimentary units otherwise like those of the Zagros Mountains, however, there are local formations. For example, the Injana Formation and Mukdadiya and Bai Hassan formations are equivalent to the Upper Fars and Bakhtyari formations, respectively (Jassim \& Buday 2006) (Fig. 2).

Although the northwestern and southern parts of the Persian Gulf present relatively stable tectonic conditions, they include several structural domains, from the northwest to southeast of the Persian Gulf: Kirkuk embayment and Mesopotamian basin in Iraq, Dibdibba-Ghawar basin in the west of the Persian Gulf, Qatar arch, and the Rub' Al-Khali and Ras Al-Khaimah basins, Dibba and Oman Mountain in the southern parts (Searle et al. 1983, Ziegler 2001, Burberry 2015). Likewise, Cenozoic rock units of the southern parts of the Persian Gulf are the same as those of the Zagros Mountains and include the Pabdeh-Jahrum, Asmari, Lower Fars (Gachsaran) and Upper Fars (Mishan) formations in Qatar, eastern UAE and the Oman Mountains (Glennie et al. 1973, Searle et al. 1983, Ziegler 2001) (Fig. 2). There were, however, major hiatuses during the late Eocene-early to middle Miocene in the Qatar arch and the northeast of Saudi Arabia and Kuwait. In these areas, Tertiary rocks include the Umm Er Radhuma (Paleocenelower Eocene), Rus and Dammam (Eocene), Hadrukh, Dam, Ghar, Hofuf, Lower Fars, Upper Fars (Miocene), Dibdibba and Bakhtyari (Pliocene) formations (Fig. 2). Late Miocene terrestrial sediments of the coastal area in the west of the UAE are known locally as the Baynunah Formation (Whybrow 1988, Whybrow et al. 1999).

There are some reports of Cenozoic vertebrate footprints from the Persian Gulf region and adjacent areas that include numerous ichnotaxa (Figs 2, 3; Tab. 1). Three reports of footprints in the Persian Gulf region are from the Zagros Mountains and others are from Cenozoic outcrops

Table 1. The list of reported Cenozoic vertebrate footprints from the Persian Gulf region.

\begin{tabular}{lllll}
\hline Age & Track maker & Location & Formation & Reference \\
\hline \multirow{2}{*}{ Pliocene } & Shore birds & Iran & Agha Jari & Lambrecht (1938) \\
& Artiodactyl/shore birds & Iran & Agha Jari & This paper \\
& Artiodactyl/shore birds & Iraq & Mukdadiya & Karim et al. (2003), Abbassi et al. (2020), this paper \\
\hline \multirow{2}{*}{ Miocene } & Artiodactyl & Oman & Barzaman & Schulp et al. (2011) \\
& Proboscidean & UAE & Baynunah & Higgs et al. (2003), Bibi et al. (2012) \\
\hline Eocene & Mammal/Bird & Iran & Kashkan & Yousefi Yeganeh et al. (2011) \\
\hline
\end{tabular}




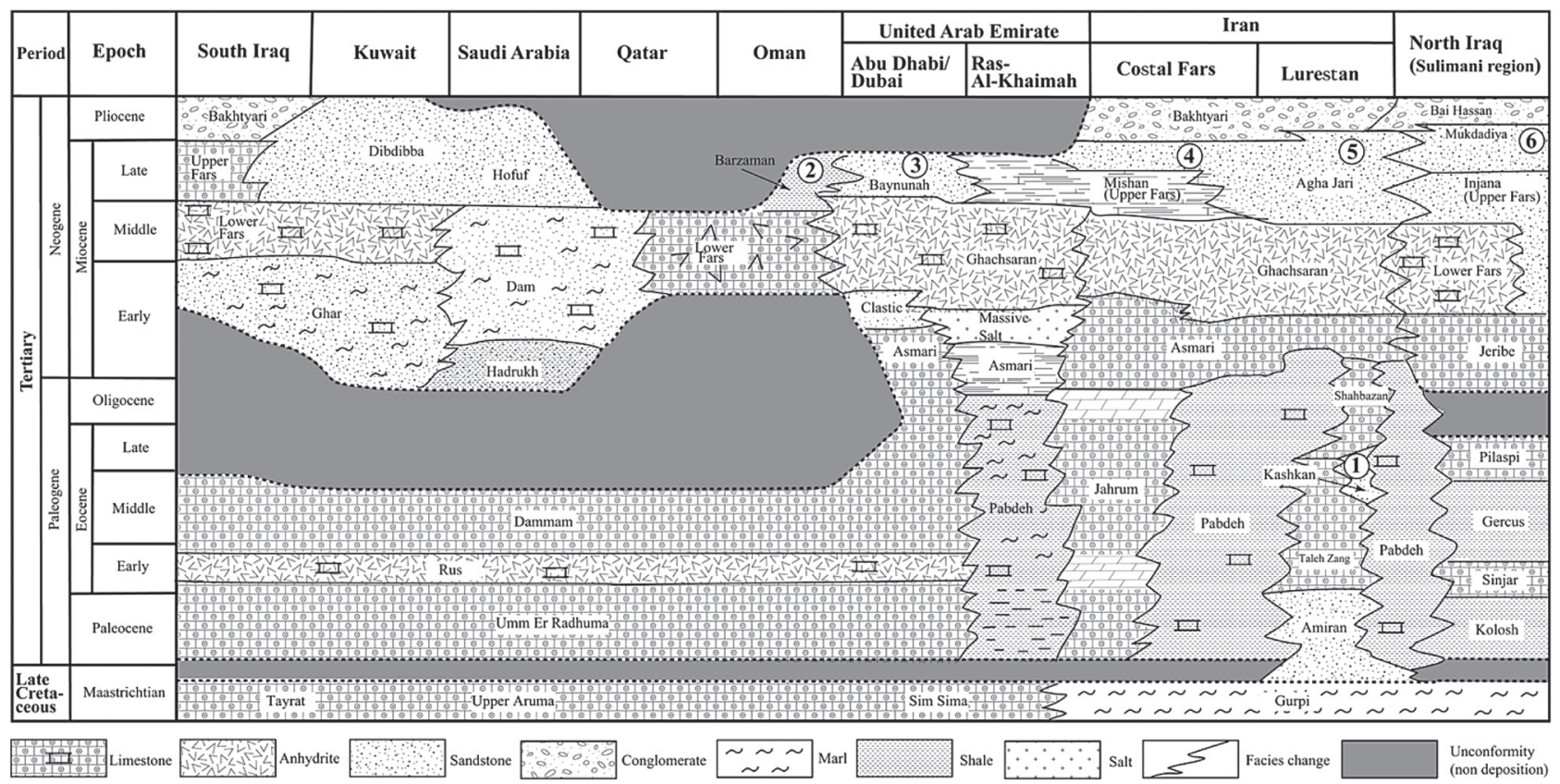

Figure 2. Stratigraphy chart of Paleogene-Neogene formations of the Persian Gulf and adjacent areas and position of the reported track sites. Modified from James \& Wynd (1965), Motiei (1993), Whybrow et al. (1999), Alavi (2004) and Jassim \& Buday (2006). Legend: 1 - bird and mammal tracks, Yousefi Yeganeh et al. (2011); 2 - large artiodactyl footprints, Schulp et al. (2011); 3 - proboscidean footprints, Bibi et al. (2012); 4 - mammal and bird footprints (this paper); 5 - bird footprints, Lambrecht (1938); 6 - bird and hoofed mammal tracks, Karim et al. (2003).

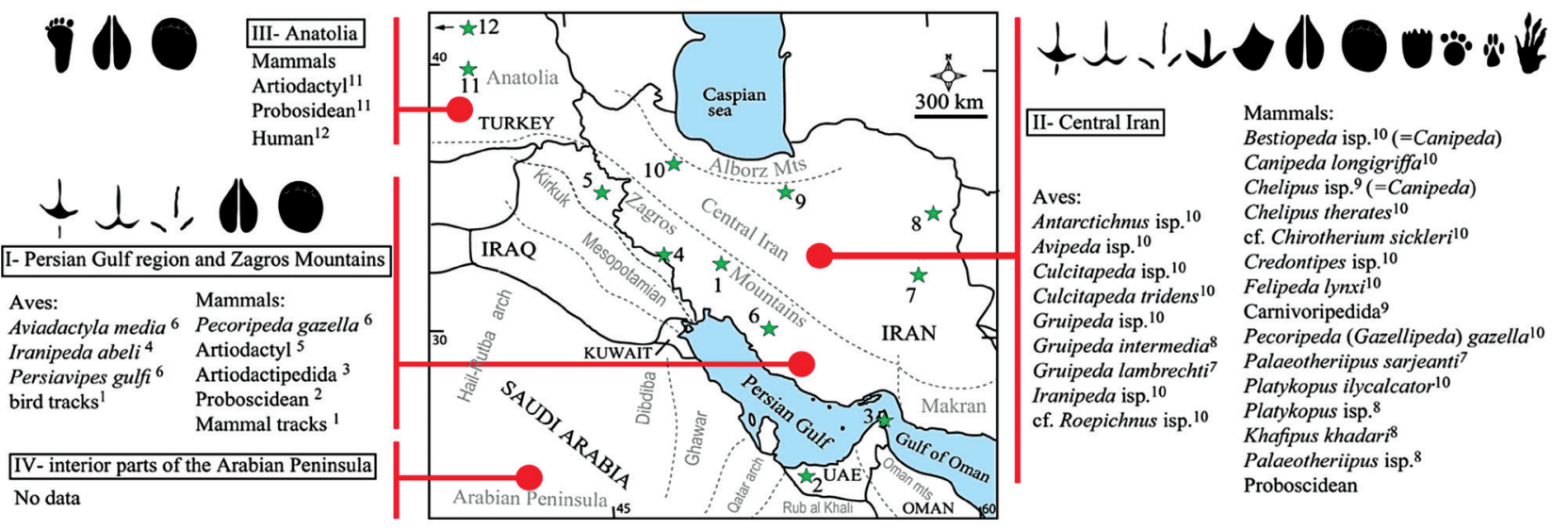

Figure 3. Distribution of reported Cenozoic vertebrate tracks in the Middle East. I - Persian Gulf region: 1 - Eocene, mammal and bird footprints, Khorram Abad area, Zagros Mountains, Yousefi Yeganeh et al. (2011); 2 - Miocene, proboscidean footprints, Mleisa area, United Arab Emirates, Bibi et al. (2012), Higgs et al. (2003); 3 - Miocene, artiodactyl footprints, Al Jissah, Oman, Schulp et al. (2011); 4 - Pliocene, shorebird footprints, Iranipeda abeli, Jabal Hamrin, Iran, Lambrecht (1938); 5 - Pliocene, bird and artiodactyl footprints, Chamchemal, Iraq, Karim et al. (2003), Abbassi et al. (2020); 6 - Pliocene, bird, and artiodactyl footprints, Konar Takhteh, Iran (this report). II - Central Iran: 7 - Eocene sediments, Birjand area Ataabadi \& Kazaee (2004); 8 - Oligocene sediments, Khaf area, Abbassi et al. (2015); 9 - Upper Red Formation, Miocene, Eyvanekey, Abbassi \& Amini (2008); 10 - Upper Red Formation, Miocene, Zanjan area, Abbassi \& Shakeri (2005), Abbassi (2010), Alavi et al. (2016), Khoshyar et al. (2016). III - Anatolia: 11 - Karayün Formation, Oligocene, Sivas basin, Mesci et al. (2019); 12 - volcanite, middle Pleistocene, Çakallar Hill, west Turkey, Ozansoy (1969).

along the southern coast of the Persian Gulf, north Arabian Peninsula (locations 1 to 6 in Fig. 3).

The first report of vertebrate footprints, not only from the Zagros Mountains but also from the Middle East, is related to the Agha Jari Formation (Pliocene) from Jabal
Hamrin, south Musian, Ilam province, southwest Iran (Lambrecht, 1938, Vialov, 1989, Abbassi et al. 2015). This footprint was called Iranipeda abeli (Lambrecht, 1938) (Vialov 1989) and considered as a valid name by Abbassi et al. (2015), although Sarjeant \& Langston (1994) 
proposed to combine this ichnospecies under Gruipeda. Based on the location of this footprint, it can be inferred that it has been sampled from the upper layers of the Agha Jari Formation, known as the Lahbari Member, and Pliocene in age (Setudehnia \& Perry 1967). Yousefi Yegeneh et al. (2011) reported bird and mammal tracks with a short description from the Kashkan Formation (Eocene) in the Khorram Abad area, in the north-central Zagros Mountains. Abundant tetradactyl large bird footprints and hoofed mammal footprints have been reported from the Mukdadiya Formation of the Chamchemal area in north Iraq, northwest Zagros Mountains (Karim et al. 2003, Abbassi et al. 2020). This formation correlates to the lower Bakhtyari Formation, and the footprints are Pliocene in age (Karim et al. 2003). Numerous tracks have been discovered from the Baynunah Formation in the Mleisa area, west Abu Dhabi Emirate, southern Persian Gulf (Higgs et al. 2003, Bibi et al. 2012). These footprints are late Miocene in age and have been made by proboscideans. One poorly preserved trackway of a large artiodactyl has been found in the restricted and collapsed cave ceiling of the coastal cliff of Al Jissah on the eastern shore of the Musandam Peninsula in the far north of Oman. This trackway was found in the middle Miocene or younger sediments of the Barzaman Formation (Schulp et al. 2011).

\section{Agha Jari Formation}

The studied vertebrate footprints were sampled from the Agha Jari Formation (Fig. 4). This rock unit consists of an alternation of grey, brown to red beds of calcareous mudstones and sandstones with gypsum veins, and has an approximate thickness of $3000 \mathrm{~m}$ (James \& Wynd 1965, Stöcklin \& Setudehnia 1991). The type section of the formation was measured in the Agha Jari oil field in the northern Persian Gulf (James \& Wynd 1965, Motiei 1993, Ghazban \& Motiei 2009). The Mukdadiya Formation in North Iraq, Dibdiba Formation in south Iraq, and the Hofuf Formation in Kuwait and Saudi Arabia have a same stratigraphic position as the Agha Jari Formation (Motiei 1993) (Fig. 2). Notwithstanding the extensive outcrops of the Agha Jari Formation in the Zagros Mountains, there are no comprehensive studies on the depositional environment of this rock unit. Continental to shallow marine conditions generally have reported for the depositional environments of the Agha Jari Formation (Motiei 1993, Ghazban \& Motiei 2009), and continental conditions are confirmed by the occurrence of terrestrial vertebrate footprints. The lithofacies of the Agha Jari Formation changes from mostly continental clastic sediments in the Dezful Embayment to marine characteristics in the Coastal Fars (Bahrami 2009, Pirouz et al. 2011, Sahraeyan \& Bahrami 2012). The Agha Jari Formation is late Miocene to Pliocene in age base on charophytes, microfauna, such as foraminifers and ostracods, and macrofauna such as bivalves (James \& Wynd 1965). The uppermost layers of the formation change to weathered gypsum-veined siltstone, silty marl and sandstone and gypsum intercalations in the northwest Zagros Mountains and are known as the Lahbari Member (Pliocene) (James \& Wynd 1965). These layers are green to gray, and climbing and oscillation ripple marks, chevron crossbedding and invertebrate trace fossils are common (Fig. 4).

\section{Study method and materials}

The study of the Agha Jari Formation footprints includes two main phases of field collecting and detailed studies in the laboratory. Specimens were sampled from the Konar Takhteh area at coordinate $29^{\circ} 39^{\prime} 13^{\prime \prime} \mathrm{N}, 51^{\circ} 20^{\prime} 04^{\prime \prime} \mathrm{E}$ (Fig. 1) and consist of six slabs of bird footprints and two large slabs of hoofed mammal footprints. These samples were deposited in the Qeshm Geopark Museum (QGM, registered by the Global Network of Geoparks (GGN), Hormozgan Province, Iran) with the collection number QGM-2888-S1 to QGM-2888-S8, and two plaster molds were prepared from the bird footprint samples numbered QGM-2888-S1 and QGM-2888-S4, and preserved with the collection numbers IFMI-575 and IFMI-576, respectively (Ichnofossil Museum of Iran, IFMI; in Zanjan Province, Iran, under construction). We used known methods for studying the morphology of bird and mammal footprints (Leonardi 1987, De Valais \& Melchor 2008). The measurement taken on footprints include stride (S) and pace (P) length, footprint width (FW), footprint length (FL), plus and without digit I (FL $+\mathrm{I}$ and $\mathrm{FL}-\mathrm{I})$, length of digits (DL) and angle between digits II-III $(=\alpha 1)$, III-IV $(=\alpha 2)$ and II-IV $(=\alpha 3)$. If the lateral digit traces are straight, the angle between digits is known as a similar measure of digit divarication, but if the digits are curved (i.e., digits II and IV form curved traces), then the measurement can become much more subjective (Camens \& Worthy 2019). Figure 5 shows the manner of measurements of the bird footprint morphology (De Valais \& Melchor 2008). Some measurements, such as digital angles and the ratio of $\mathrm{FL} / \mathrm{FW}$, were useful for ichnotaxonomic determinations of the webbed bird or artiodactyl footprints. Photographic analysis and sketches of the outlines of the footprints were useful in visualization for the morphology of studied footprints. Digital three-dimensional photos of bird footprints were obtained by high-resolution digital photogrammetry, according to a standard protocol for ichnological studies (Falkingham 2012, Falkingham et al. 2018). A Canon EOS-M2 photographic camera and the software packages Agisoft PhotoScan Professional (Educational License), Cloud Compare, were used for this method. 
Figure 4. Agha Jari Formation outcrops and stratigraphic column in the Konar Takhteh area. - A Mishan and Agha Jari formations boundary (view towards south). $\bullet$ $\mathrm{B}, \mathrm{C}-$ alternations of sandstone and shales of the Agha Jari Formation, south Konar Takhteh. • D - simplified stratigraphic column of the Agha Jari Formation in the south Konar Takhteh (A and D modified from Yazdi et al. 2013, with permission).
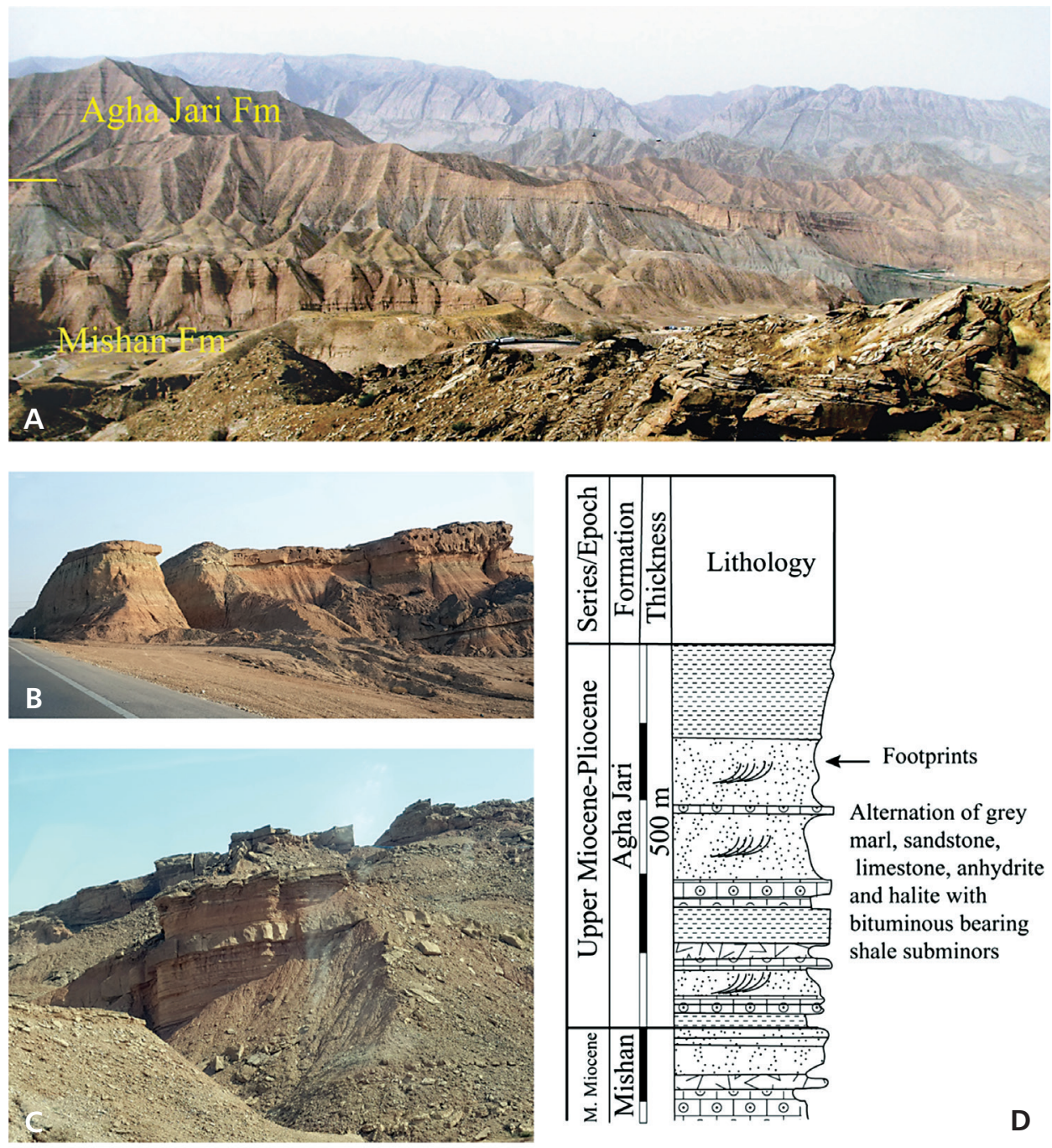

\section{Systematic ichnology}

Ichnofamily Koreanornipodidae Lockley et al., 2006

\section{Ichnogenus Koreanaornis Kim, 1969}

\section{Koreanaornis hamanensis Kim, 1969}

Figures 6, 8, 9

Material. - More than 50 collected footprints, imprinted in five sampled slabs.

Description: Small tetradactyl footprints were preserved as convex hyporelief in the lower bedding plane of fine- to medium-grained brown sandstone. These footprints include three slender digit imprints, isolated or joined at the heel. The middle digit (digit III) impression is larger than the lateral ones. The hallux impression (digit I) is smallest and is only known from specimens $\mathrm{S} 3$ and S4. Claw impressions are visible at the tips of digit impressions. Digit impressions are lanceolate. Digital pads are not commonly recognizable, but some footprints show three pads in the medial or lateral digits. Digit imprints are arranged asymmetrically in the footprints so that digit II is smaller than digit IV. Only three trackways were distinguished. Table 2 shows the measurements of these footprints.

Remarks. - The morphology and size of the studied footprints are very similar to Koreanaornis hamanensis from the Cretaceous Haman Formation of Korea (Kim 1969). Koreanaornis hamanensis is tetradactyl tracks, but generally the digit I impression may not be well preserved and such tracks are reported as tridactyl imprints (Lockley et al. 1992, 2006, 2012; Camens \& Worthy 2019). The authors compared $K$. hamanensis to tri- to tetradactyl avian Cretaceous and Cenozoic footprints. Thus, K. hamanensis differs from Goseongornipes markjonesi Lockley et al., 2006, by greater width, wide divarication angles between 
Table 2. Measurements on Koreanaornis hamanensis in the studied samples (in millimeters).

\begin{tabular}{|c|c|c|c|c|c|c|c|c|c|}
\hline \multirow[b]{2}{*}{ TL no. } & \multirow[b]{2}{*}{$\mathrm{S}$} & \multirow[b]{2}{*}{$\mathrm{P}$} & \multirow[b]{2}{*}{$\mathrm{FL}$} & \multirow[b]{2}{*}{ FW } & \multicolumn{3}{|c|}{ DL } & \multicolumn{2}{|c|}{ Ang. } \\
\hline & & & & & II & III & IV & $\begin{array}{c}\text { II-III } \\
\left(\alpha_{1}\right)\end{array}$ & $\begin{array}{c}\text { III-IV } \\
\left(\alpha_{2}\right)\end{array}$ \\
\hline 1 & - & - & 13.6 & 22.7 & 14 & 13.6 & 11.3 & 40 & 59 \\
\hline 2 & - & - & 16 & 26 & 13.5 & 11.6 & 13 & 38 & 68 \\
\hline 3 & & & 10.7 & 18.4 & 8 & 8 & 9 & 55 & 70 \\
\hline 4 & & & 15.7 & 21 & 10 & 12 & 8 & 57 & 50 \\
\hline 5 & & & 23.6 & 22.3 & 11.8 & 18.2 & 9.2 & 45 & 60 \\
\hline 6 & & & 9 & 18 & 7 & 8 & 7 & 50 & 63 \\
\hline 7 & & & 26.3 & 29 & 9.2 & 17.1 & 13.1 & 77 & 54 \\
\hline 8 & & & 26 & 30 & 13 & 18 & 10 & 68 & 45 \\
\hline 9 & & & 10 & 14 & 7 & 8 & 6 & 50 & 58 \\
\hline 10 & & & 20 & 22 & 9 & 18 & 12 & 40 & 65 \\
\hline 11 & & & 8 & 10 & 5 & 7 & 4 & - & - \\
\hline 12 & & & - & - & - & - & - & - & - \\
\hline 13 & & & 20 & 21 & 11 & 18 & 8 & 53 & 50 \\
\hline 14 & 90 & 175 & 23 & 25 & 10 & 16 & 8 & 38 & 80 \\
\hline 15 & & & 15 & 24 & 7 & 12 & 10 & 48 & 60 \\
\hline 16 & & & 20 & 25 & 10 & 13 & 11 & 50 & 65 \\
\hline 17 & 50 & - & 18 & 23 & 9 & 14 & 10 & 55 & 65 \\
\hline 18 & & & 17 & 30 & 13 & 15 & 12 & 62 & 65 \\
\hline 19 & & & 13 & 27 & 17 & 12 & 10 & 53 & 65 \\
\hline 20 & & & 15 & 21 & 6 & 12 & 11 & 52 & 60 \\
\hline 21 & & & 20 & 30 & 13 & 17 & 12 & 80 & 55 \\
\hline 22 & & & 19.1 & 30.8 & 15 & 11 & 14 & 65 & 75 \\
\hline 23 & & & 14.1 & 23.3 & 12 & 19 & 13 & 40 & 45 \\
\hline 24 & & & 17 & 22 & 12 & 12.5 & 12 & 29 & 52 \\
\hline 25 & & & 23 & 35 & 16.6 & 17 & 19 & 25 & 115 \\
\hline 26 & & & 46 & 46 & 33 & 31 & 17 & 40 & 88 \\
\hline 27 & & & 28 & 32 & 12 & 21 & 12 & 50 & 73 \\
\hline 28 & & & 11 & 28 & 10 & 13 & 14 & 85 & 45 \\
\hline 29 & & & 28 & 29 & 8 & 21 & 17 & 75 & 40 \\
\hline 30 & & & 19 & 19 & 8 & 13 & 14 & 75 & 70 \\
\hline 31 & & & 20.8 & 27.5 & 10 & 17.5 & 19 & 53 & 53 \\
\hline 33 & 69 & 127 & 23 & 21 & 12 & 16 & 11 & 80 & 32 \\
\hline 34 & & & 18 & 22.5 & 7.5 & 13 & 14 & 65 & 50 \\
\hline 35 & 54 & - & 22 & 24 & 13 & 14 & 13 & 65 & 35 \\
\hline $40-44$ & 102 & 214 & & & & & & & \\
\hline mean & & & 20.45 & 26.6 & 12 & 15.8 & 12.7 & 56.2 & 60.8 \\
\hline
\end{tabular}

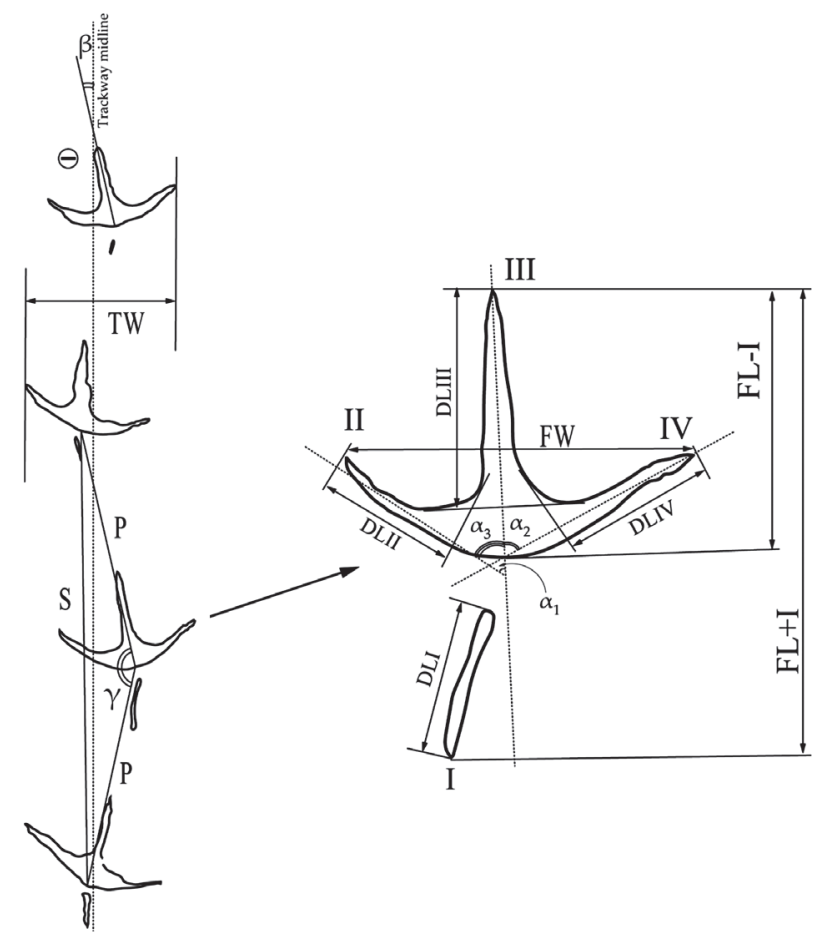

Figure 5. Method of measurement of geometry of bird footprints. Legend: S - stride length; P - pace length; TW - trackway width; I, II, III, and IV - digit numbers; DLI-IV - digit length; FL + I and FL - I footprint length plus and without digit I, respectively; FW - footprint width; $\alpha 1-3$ - interdigital angle between digits II-III, III-IV and II-IV, respectively; $\beta$ - angle of footprint rotation as negative (-) or inward to midline of trackway; $\gamma$ - pace angulation. The trackway (a) of the sample S1 (IFMI-575) used as geometry pattern (see S1 in Fig. 6).

digits II and IV, and hallux impressions (Kim et al. 2013). Kordos (1985) however, established Aviadactyla media for small tridactyl bird footprints, and the main characteristics of this ichnospecies are the asymmetry of the footprint, and thin, stick-like, shallowly imprinted digit imprints. The studied footprints of $K$. hamanensis show higher digital angles between digit II and IV $\left(112^{\circ}\right)$ than in A. media.

The five ichnospecies introduced for Koreanaornis are K. hamanensis Kim, 1969, K. lii Xing et al., 2016, K. sinensis Lockley et al., 2008, K. dodsoni Xing et al. 2011 and $K$. anhuiensis Xing et al., 2018. Small size, wide, sub-symmetric, functionally tridactyl tracks with slender digit impressions and wide divarication angles between digits II and IV are the main characteristics of these ichnospecies. Koreanaornis hamanensis, K. dodsoni and $K$. lii have digit traces that do not join proximally on most tracks, but digit traces of $K$. anhuiensis connect proximally to a metatarsophalangeal pad (Xing et al. 2018). Koreanaornis dodsoni differs from K. hamanensis tracks in having smaller divarication angles between digits II and IV, greater overall track length and width, persistent absence of digit I, and absence of digital pad impressions 
(Xing et al. 2011). K. lii is distinguished by a proximal footprint margin that is obtuse to nearly perpendicular to the digit III trace, high digit II-IV divarication, and a small digit I impression with a digit divarication I-II between $134^{\circ}-160^{\circ}$ (Xing et al. 2016). Tracks named Aquatilavipes sinensis Zhen et al., 1995 from Sichuan Province, China, are probably a junior synonym of Koreanaornis hamanensis, but Anfinson et al. (2009) reclassified $A$. sinensis under the new combination $K$. sinensis Lockley et al., 2008. The holotype of $K$. sinensis is $3.1 \mathrm{~cm}$ and 3.8 in length and width, respectively, with digit divarication of $115^{\circ}$ (Zhen et al. 1995).

Ichnofamily Ignotornidae Lockley et al., 2006

\section{Ichnogenus Persiavipes nov.}

Type species. - Persiavipes gulfi ichnosp. nov.
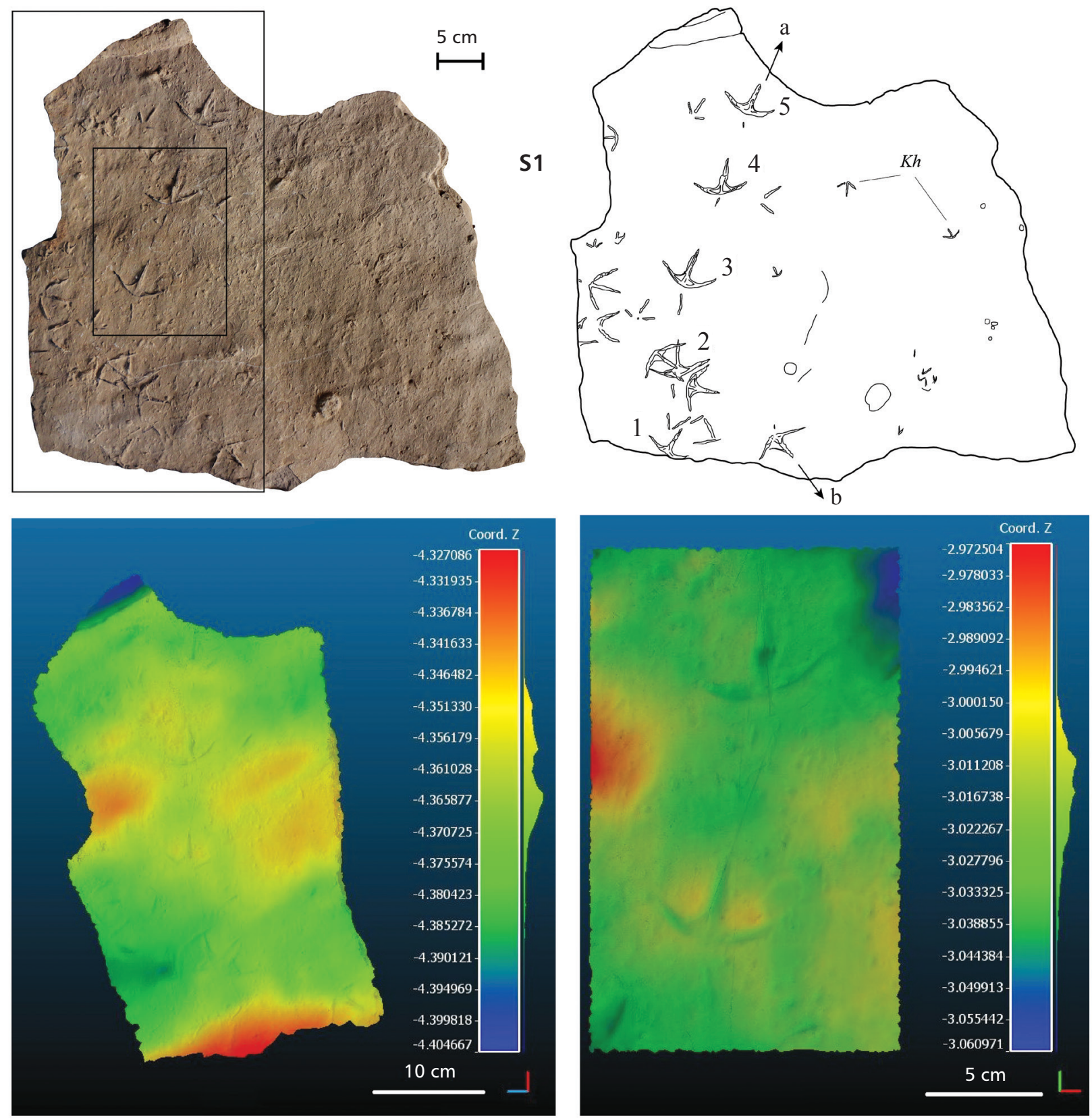

Figure 6. Photo, sketch and three-dimensional photogrammetric images of bird footprints in the studied slab of sample QGM-2888-S1 include Koreanaornis hamanensis $(\mathrm{Kh})$, and holotype trackway of Persiavipes gulfi (trackway a), the quadrangles show position of photogrammetric images on the plaster molds. The perpendicular colour lines are $\mathrm{X}$ and $\mathrm{Y}$ coordinates and $\mathrm{Z}$ coordinates shows surface topographic variations. 
Table 3. Measurements on Persiavipes gulfi in the studied samples S1 to S5 (in centimeters).

\begin{tabular}{|c|c|c|c|c|c|c|c|c|c|c|c|c|c|c|c|}
\hline \multirow[b]{2}{*}{ Sample No. } & \multirow[b]{2}{*}{ TW No. } & \multirow[b]{2}{*}{$\begin{array}{c}\text { Footprint } \\
\text { No. }\end{array}$} & \multirow[b]{2}{*}{$\mathrm{S}$} & \multirow[b]{2}{*}{$\mathrm{P}$} & \multirow[b]{2}{*}{ TW } & \multirow[b]{2}{*}{ FW } & \multicolumn{2}{|c|}{ FL } & \multicolumn{4}{|c|}{ DL } & \multicolumn{3}{|c|}{ Interdigital angel } \\
\hline & & & & & & & $+\mathrm{I}$ & $-\mathrm{I}$ & I & II & III & IV & $\begin{array}{c}\text { II-III } \\
\left(\alpha_{1}\right)\end{array}$ & $\begin{array}{c}\text { III-IV } \\
\left(\alpha_{2}\right)\end{array}$ & $\begin{array}{c}\text { II-IV } \\
\left(\alpha_{3}\right)\end{array}$ \\
\hline \multirow{9}{*}{ S1 } & \multirow{5}{*}{$\begin{array}{c}\mathrm{a} \\
\text { (Holotype) }\end{array}$} & 1 & \multirow{5}{*}{20.1} & \multirow{5}{*}{9.95} & \multirow{5}{*}{5} & 4.7 & - & 3.3 & -- & 2.3 & 2.3 & 2.7 & 61 & 72 & 136 \\
\hline & & 2 & & & & 6.5 & 6.6 & 4.5 & 1.5 & 1.8 & 3.1 & 2.7 & 70 & 60 & 132 \\
\hline & & 3 & & & & 5.7 & 6.7 & 4 & 2.25 & 1.4 & 2.7 & 2 & 52 & 57 & 109 \\
\hline & & 4 & & & & 5.7 & 6.1 & 4.2 & 1.5 & 1.8 & 3.2 & 1.8 & 70 & 55 & 125 \\
\hline & & 5 & & & & 5.7 & 5.9 & 4.3 & 1.1 & 2 & 3 & 2.3 & 63 & 62 & 125 \\
\hline & \multirow{4}{*}{$\mathrm{b}$} & 1 & \multirow{4}{*}{15.5} & \multirow{4}{*}{8.7} & \multirow{4}{*}{5.5} & - & - & - & - & - & - & - & 45 & - & - \\
\hline & & 2 & & & & 12.7 & 10.5 & 7.5 & - & 3.7 & 3.7 & 3.7 & 75 & 50 & 123 \\
\hline & & 3 & & & & 12.4 & 11.6 & 8.2 & - & 3.7 & 5.2 & 3.5 & 47 & 75 & 120 \\
\hline & & 4 & & & & 14.2 & 12.7 & 8.2 & 1.0 & 4.1 & 3 & 3.7 & 70 & 62 & 130 \\
\hline \multirow{4}{*}{$\mathrm{S} 2$} & \multirow{4}{*}{$\mathrm{a}$} & 1 & & & & 5.4 & 4.4 & 3 & - & 1.9 & 2.1 & 1.5 & 75 & 62 & 138 \\
\hline & & 2 & & 110 & 7 & 5.8 & 5.9 & 3.5 & 1.5 & 1.9 & 2.7 & 1.9 & 48 & 80 & 130 \\
\hline & & 3 & 20.0 & 11.2 & 1 & 5.1 & 6.1 & 3.5 & 1.7 & 1.9 & 2.3 & 1.9 & 68 & 57 & 125 \\
\hline & & 4 & & & & 3.8 & 5.4 & 3.6 & 1.5 & 1.5 & 2.3 & 1.9 & 45 & 55 & 82 \\
\hline & & 1 & & & & 5.8 & 6 & 3.7 & 1.8 & 1.8 & 2.8 & 2.3 & 60 & 57 & 117 \\
\hline & . & 2 & 22 & 108 & 66 & 6.5 & 5.5 & 3.5 & 1.6 & 2 & 2.5 & 1.8 & 60 & 75 & 135 \\
\hline & $\mathrm{a}$ & 3 & 22 & 10.0 & 0.0 & 6.3 & 6.5 & 4 & 1.5 & 2.3 & 2 & 1.3 & 67 & 50 & 120 \\
\hline $\mathrm{S}_{2}$ & & 4 & & & & 6 & 7 & 4 & - & 2 & 2.3 & 1.5 & 65 & 67 & 130 \\
\hline & $\mathrm{b}$ & 1 & & 4 & & 6.3 & 7 & 3.5 & - & 1.5 & 2.5 & 1.8 & 47 & 81 & 125 \\
\hline & & 2 & & & & 5.3 & 6.3 & 4.2 & 1.5 & 2 & 2.7 & 2.3 & 65 & 54 & 117 \\
\hline & $\mathrm{c}$ & 1 & - & - & - & 2.5 & 4 & 2.3 & 1.2 & 0.7 & 1.2 & 0.7 & 57 & 63 & 120 \\
\hline & d & 1 & & 8 & & - & - & 2 & - & 0.7 & 1.2 & - & 55 & - & - \\
\hline & & 2 & & 0 & & 2.4 & 3 & 2 & 0.7 & 0.7 & 1 & 0.7 & 33 & 58 & 92 \\
\hline & & 1 & & & & 5.3 & 6.6 & 4.2 & 2.0 & 1.6 & 2.6 & 2.6 & 62 & 55 & 118 \\
\hline & $\mathrm{a}$ & 2 & 19 & 9.4 & 5.1 & 5.3 & 7.5 & 4.2 & 2.5 & 1.6 & 2.6 & 1.4 & 50 & 63 & 113 \\
\hline & & 3 & & & & 4.7 & 6.3 & 4.2 & 2.2 & 1.9 & 2.5 & 1.3 & 63 & 47 & 112 \\
\hline & & 1 & & & & 5.7 & 5.5 & 3.7 & - & 1.6 & 2.2 & 1.6 & 77 & 60 & 140 \\
\hline SA & & 2 & & & & 5.5 & 6 & 4.4 & 1.8 & 1.6 & 2.3 & 1.7 & 53 & 60 & 114 \\
\hline & & 3 & & & & 6 & 8.1 & 5 & 1.5 & 2.1 & 3.4 & 2.5 & 70 & 50 & 122 \\
\hline & $\mathrm{b}$ & 4 & 15 & 7.8 & 6.1 & 5.8 & 7.4 & 5.3 & - & 2.3 & 3.4 & 2.1 & 60 & 54 & 104 \\
\hline & & 5 & & & & 6.3 & 6 & 3.9 & 1.5 & 1.7 & 2.2 & 2.2 & 60 & 50 & 102 \\
\hline & & 6 & & & & 6.1 & 5.3 & 3.7 & 1.5 & 2.1 & 2.2 & 1.9 & 65 & 60 & 125 \\
\hline & & 7 & & & & 6.5 & 5.3 & 3.9 & - & 2.1 & 2.5 & 2.1 & 60 & 65 & 126 \\
\hline & & 1 & & & & 5.3 & - & 3 & - & 1.7 & 2.6 & 1.8 & 45 & 70 & 115 \\
\hline & 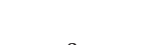 & 2 & 0.5 & 5 & 6 & 4.4 & - & 4.7 & - & 1.5 & 2.7 & 1.7 & 48 & 48 & 85 \\
\hline S5 & a & 3 & 9.3 & 3.0 & 0 & 6 & - & 3.2 & - & 3.2 & 2.2 & 2.2 & 50 & 52 & 104 \\
\hline & & 4 & & & & 5 & 4.8 & 3.7 & - & 2.2 & 2.3 & 1.8 & 55 & 52 & 107 \\
\hline & $\mathrm{b}$ & 1 & - & - & & 4.8 & 6.8 & 3.4 & 1.6 & 1.8 & 2 & 2.2 & 40 & 50 & 90 \\
\hline & mean & & 17.3 & 8.2 & & 6.04 & 6.5 & 4.09 & 1.58 & 1.96 & 2.54 & 2.03 & 58.2 & 59.8 & 117.3 \\
\hline
\end{tabular}


Figure 7. Well preserved footprint in the holotype trackway of Persiavipes gulfi, the third footprint of a trackway (a) of sample QGM-2888-S1, scale bar equals $1 \mathrm{~cm}$. The perpendicular colour lines are $\mathrm{X}$ and $\mathrm{Y}$ coordinates and $\mathrm{Z}$ coordinates shows surface topographic variations.

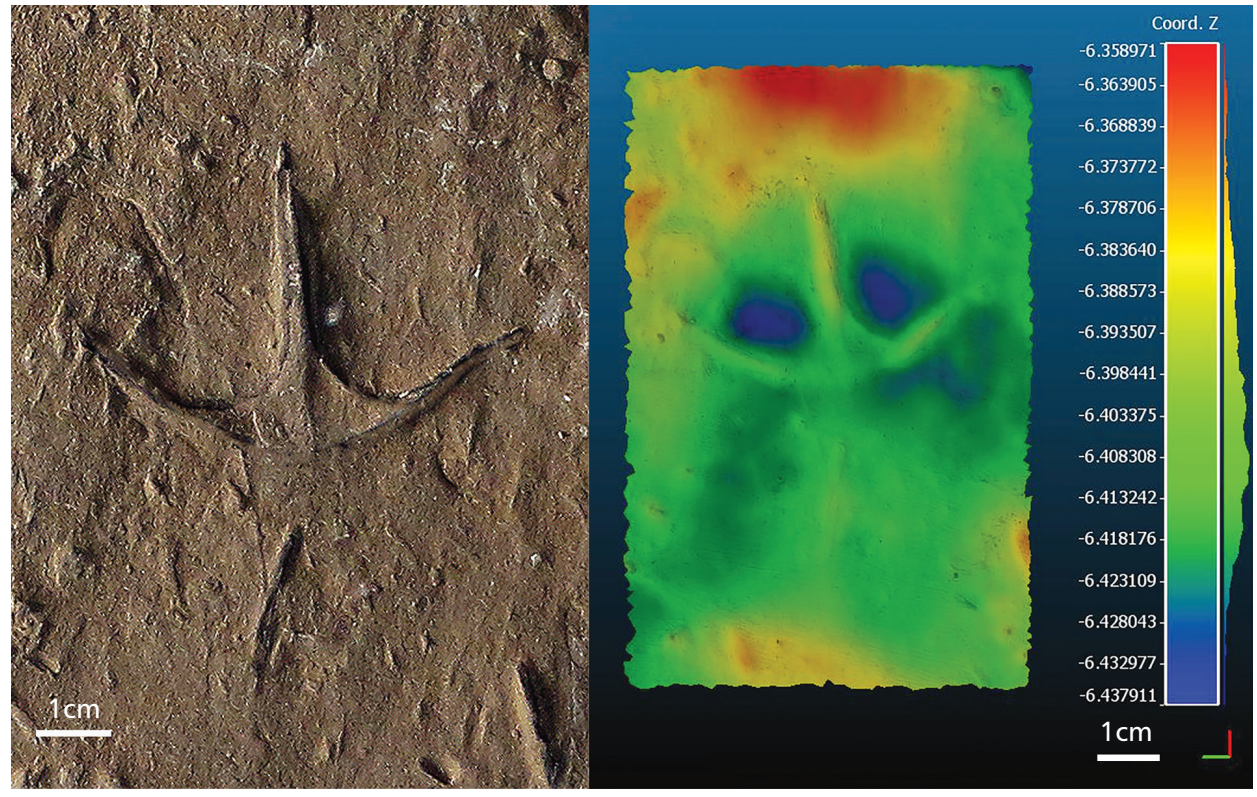

Etymology. - Persi from Persia, the ancient name of Iran; avi from Greek Avia, and pes, Greek, pod.

Diagnosis.- Tetradactyl bird footprints, medium in size, composed of three slender, acuminate digit imprints, with claw marks. Digits connect to each other proximally with a semipalmate webbing. Digit III is longer than the lateral digits (II, IV), and the interdigital angle between II-III is smaller than the III-IV angle. A thin and delicate digit I imprint is long and oblique to the midline of the footprint. Digit I imprint does not touch the other digit imprints. Footprints slightly inward rotated.

\section{Persiavipes gulfi ichnosp. nov.}

Figures 6-8

Material. - Twenty-five complete footprints arranged in seven trackways in five samples [sample QGM-2888-S1 (IFMI-575, plaster mold) and sample QGM-2888-S4 (IFMI-576, plaster mold) and samples QGM-2888-S3 to S5]. Holotype: Footprints of the trackway (a) in QGM2888-S1 (S1 in Fig. 6, Fig. 7).

Etymology. - Gulfi from the Persian Gulf, sampled materials were located around the Persian Gulf.

Diagnosis. - As for the ichnogenus.

Description. - The footprints include four slender and straight digit imprints. Lateral digits arranged approximately symmetrical around the middle digit. Averages of interdigital angles are $58.2^{\circ}$ and $59.8^{\circ}$ between II-III and III-IV, respectively. Digit III is longer than the lateral digit imprints. No digit pad imprints are visible. Digit I imprint is smallest, has a needle shape, and is more oblique than the mid-line of footprints and separate from the forward-directed digit imprints. Interdigital web imprints cover about a quarter of digit length. The swollen rim of the interdigital web is retroflexed. Footprints are rounded proximally with slight relief. Table 3 shows the measurements on the studied trackways of Persiavipes gulfi.

Remarks. - The oldest bird or bird-like footprints have been reported from the Middle Jurassic (Lockley et al. 1992, Belvedere et al. 2011). Webbed bird footprints include Gyeongsangornipes lockleyi Kim et al., 2013 and Ignotornis gajinensis Kim et al., 2012 from the Early Cretaceous of South Korea. There are numerous reports of webbed bird footprints around the world, among them, there are 14 named ichnogenera that have been established for this kind of bird footprints (Tab. 4). The origin of webbed feet is related to the feeding habits and lifestyle of basal ornithuromorphs, which appeared in the waders and aquatic ornithuromorphs. Webbed footprints exclusively belong to birds or bird-like ornithuromorphs, and no webbed footprints have been reported for non-avian theropod dinosaurs. Although there are "webbed" toes on the dinosaur footprint Irenesauripus mclearni from the Lower Cretaceous of British Columbia (Harrington et al. 2005), this may be due to the substrate consistency, and it is not a truly webbed footprint. Three webbed toe imprints may be described as fully-webbed, such as Anatipeda anas Panin \& Avram, 1962, Anatipeda californica Sarjeant \& Reynolds, 2001, or on a part of middle digit (III) and fully on lateral toes, such as in Leptoptilostipus pyrenaicus Payros et al., 2000, Presbyorniformipes feduccii Yang et al., 1995, Dongyangornipes sinensis Azuma et al., 


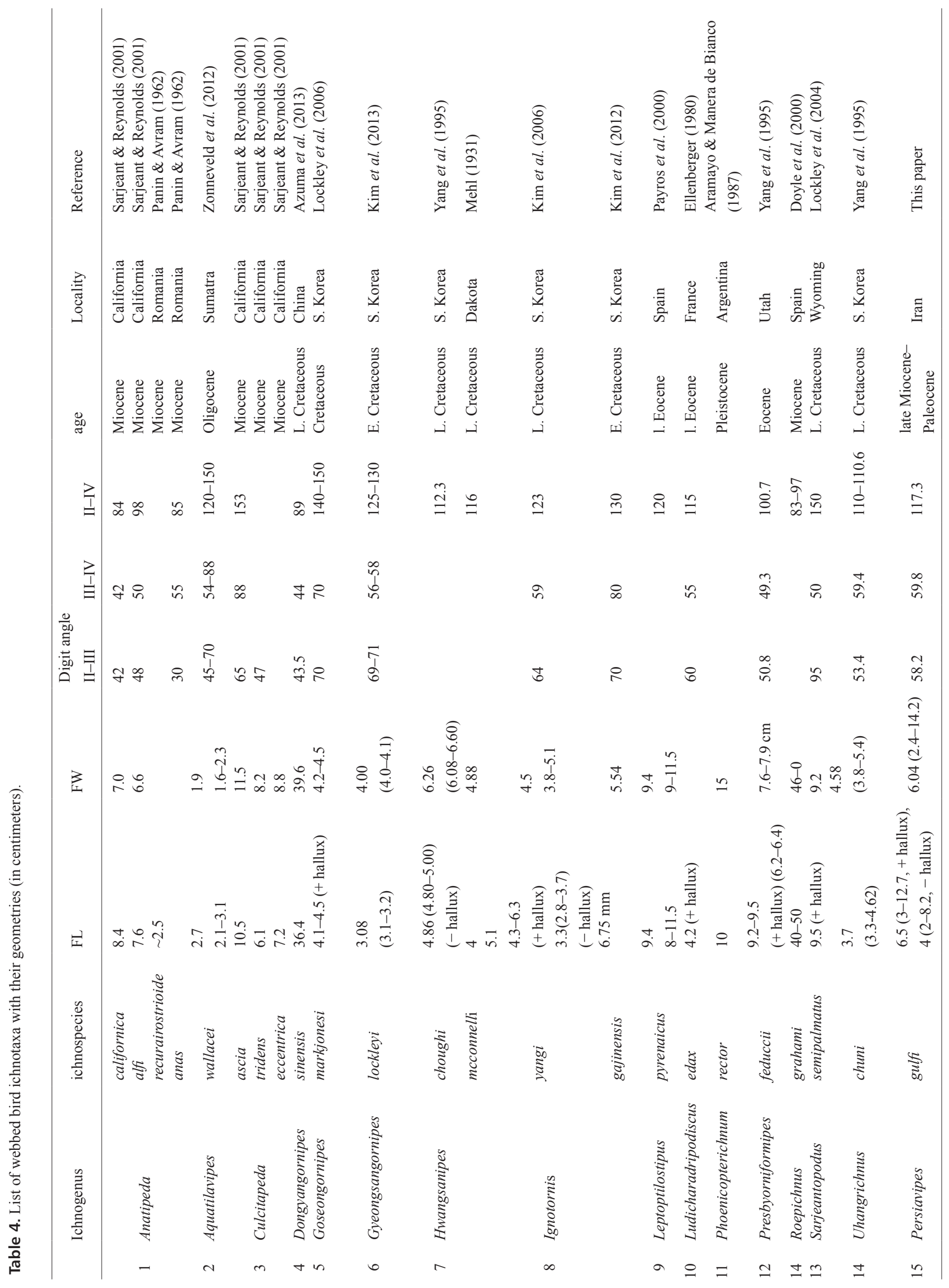



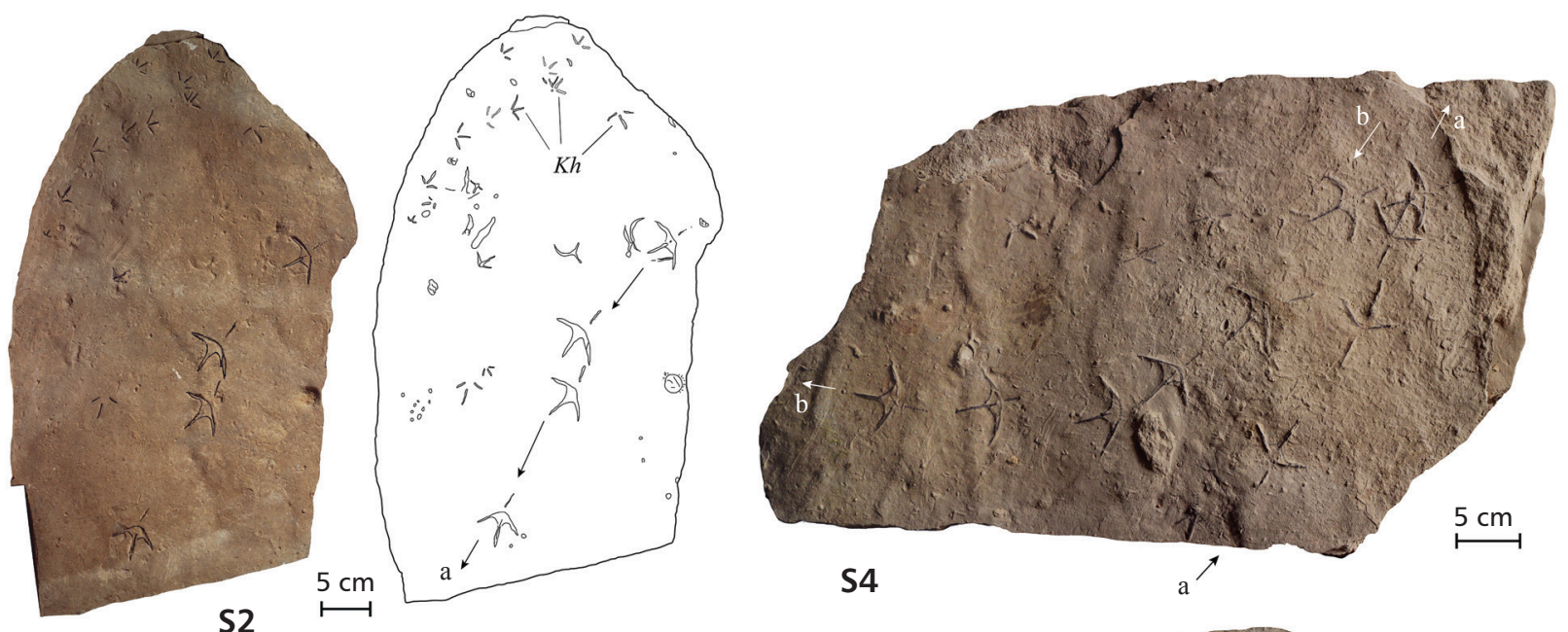

S2
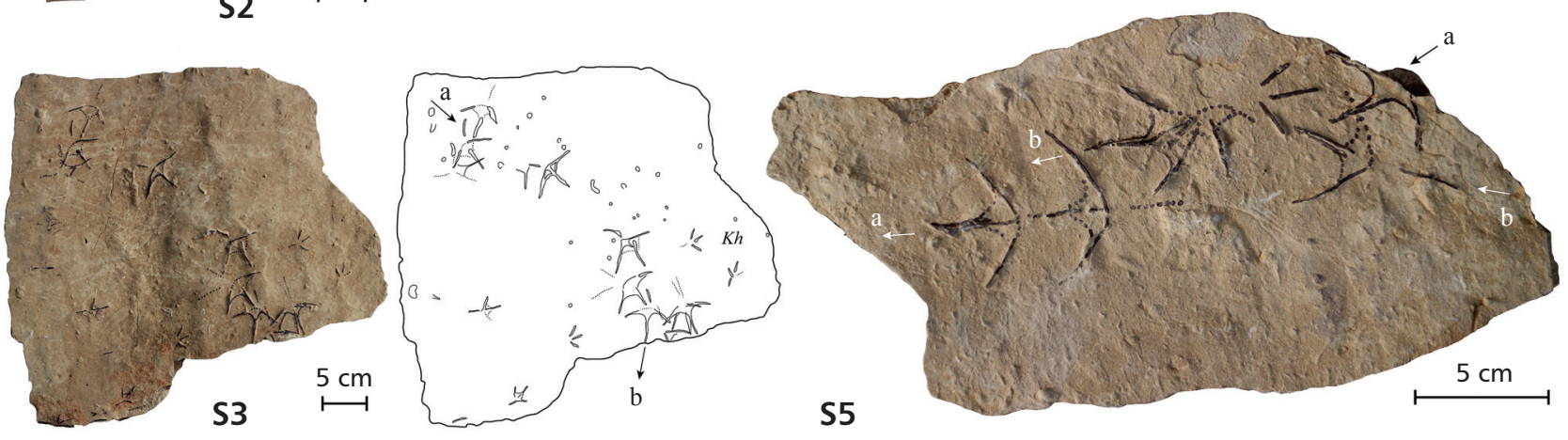

Figure 8. Persiavipes gulfi as semipalmate bird footprints and Koreanaornis hamanensis (Kh), in the samples QGM-2888-S2 to S5. Scale bars in cm.

2013 or asymmetrically only between the II-III or III-IV digit imprints, such as in Sarjeantopodus semipalmatus Lockley et al., 2004. Persiavipes gulfi is a tetradactyl semipalmate footprint, and the interdigital web involves the three forward-directed digits.

We classify Persiavipes under the ichnofamily Ignotornidae Lockley et al., 2006, together with the ichnogenera Ignotornis, Hwangsanipes, Goseongornipes and Uhangrichnus Yang et al., 1995. The ichnofamily Ignotornidae includes tetradactyl slightly assymetrical tracks with posteriorly directed hallux impressions typically showing significant medial rotation towards the trackway midline (Lockley et al. 1992). The diagnosis of the ichnofamily Ignotornidae was emended by Kim et al. (2012), and they considered it as tetradactyl bird tracks showing prominent, postero-medially directed hallux impressions comprising about one-third of total track length. The hypex between digits III and IV is more anteriorly situated than the hypex between digits II and III, with the tendency for development of an asymmetrical, semipalmate web that is more strongly developed between digits III and IV. Digit divarication between II and IV averages at least $110-120^{\circ}$ (Tab. 5). Digit pad impressions are variable but sometimes show a 2-3-4 phalangeal formula corresponding to digits
II, III, and IV. Step is typically short with a strong tendency towards inward rotation.

The ichnofamily Gruipedidae is known as tetradactyl avian footprints showing an axis either coinciding with, or at an angle to, that of digit III. Claws may be distinguishable, but the digits give no indication of digital pads or interpad spaces: the metatarsal pad is most often not impressed. Digits united or separated proximally. Webbing absent or limited to the most proximal part of the interdigital angle (Sarjeant \& Reynolds 2001). At first, Gruipeda and Alaripeda were placed in Gruipedidae (Sarjeant \& Reynolds 2001). In a later review, Gruipeda, Ardeipeda, Antarchtichnus, Ignotornis and Tetraornithopedia have been considered as ichnogenera of Gruipedidae (Lockley \& Harris 2010). Among these ichnogenera, only Ignotornis is semipalmate, thus is belongs to Ignotornidae. Digit divarication in Persiavipes is the same as Ignotornis and smaller than Goseongornipes. Asymmetry of Ignotornidae is visible in the position of the hypex, so that the hypex between digits III and IV is more anteriorly situated than the hypex between digits II and III (Kim et al. 2006), which is visible more and less in Persiavipes (Figs 6-8). The range of FL + I of Ignotornidae is about $3.2-6.7 \mathrm{~cm}$, and ratios of $\mathrm{FL} / \mathrm{FW}$ and DLI/FL in the Ignotornidae equal to $0.67-1.37$ 
Table 5. Geometry of the ichnogenera of the ichnofamily Ignotornidae (in centimeters) [data from Kim et al. (2012) (*); Mehl (1931), fig. 1 (**); Yang et al. (1995), fig. $5(* * *)$; and Lockley et al. (2006), figs 9c and 20d (****)].

\begin{tabular}{|c|c|c|c|c|c|c|c|c|c|c|c|}
\hline \multirow[b]{2}{*}{ Ichnofamily } & \multirow[b]{2}{*}{ Ichnogenus } & \multicolumn{2}{|c|}{ FL } & \multirow[b]{2}{*}{ FW } & \multirow[b]{2}{*}{$\mathrm{FL} / \mathrm{FW}$} & \multirow[b]{2}{*}{ II ${ }^{\wedge} \mathrm{VV}$} & \multirow[b]{2}{*}{$\mathrm{DLI} / \mathrm{FL}$} & \multirow{2}{*}{$\begin{array}{c}\text { Footprint } \\
\text { rotation } \\
(\beta)\end{array}$} & \multirow{2}{*}{$\begin{array}{l}\text { Pace } \\
\text { angle } \\
(\gamma)\end{array}$} & \multirow[b]{2}{*}{ web } & \multirow[b]{2}{*}{ Reference } \\
\hline & & $+\mathrm{I}$ & $-\mathrm{I}$ & & & & & & & & \\
\hline \multirow{4}{*}{ Ignotornidae } & Ignotornis & $\sim 5.5^{*}$ & $\sim 4^{*}$ & 4 & $1.37-1$ & $105-125$ & 0.33 & -15 & $130^{* *}$ & $\begin{array}{l}\text { Semipalmated } \\
\quad \text { Slightly } \\
\text { III-IV > II-III }\end{array}$ & Mehl (1931) \\
\hline & Hwangsanipes & $6.68^{* * *}$ & 4.86 & 6.26 & $1.06-0.77$ & 112.3 & $\sim 0.28^{* * *}$ & $-10^{* * *}$ & 165 & Full webbed & $\begin{array}{c}\text { Yang et al. } \\
\quad(1995)\end{array}$ \\
\hline & Goseongornipes & 4.3 & 3.25 & 4.35 & $0.98-0.74$ & $140-150$ & $0.22-0.25$ & $\sim-25^{* * * *}$ & 170 & Semipalmated & $\begin{array}{l}\text { Lockley et al. } \\
\text { (2006) }\end{array}$ \\
\hline & Persiavipes & 6.5 & 4.09 & 6.04 & $1.07-0.67$ & 117.3 & 0.26 & -15.2 & 165 & Semipalmated & This paper \\
\hline
\end{tabular}
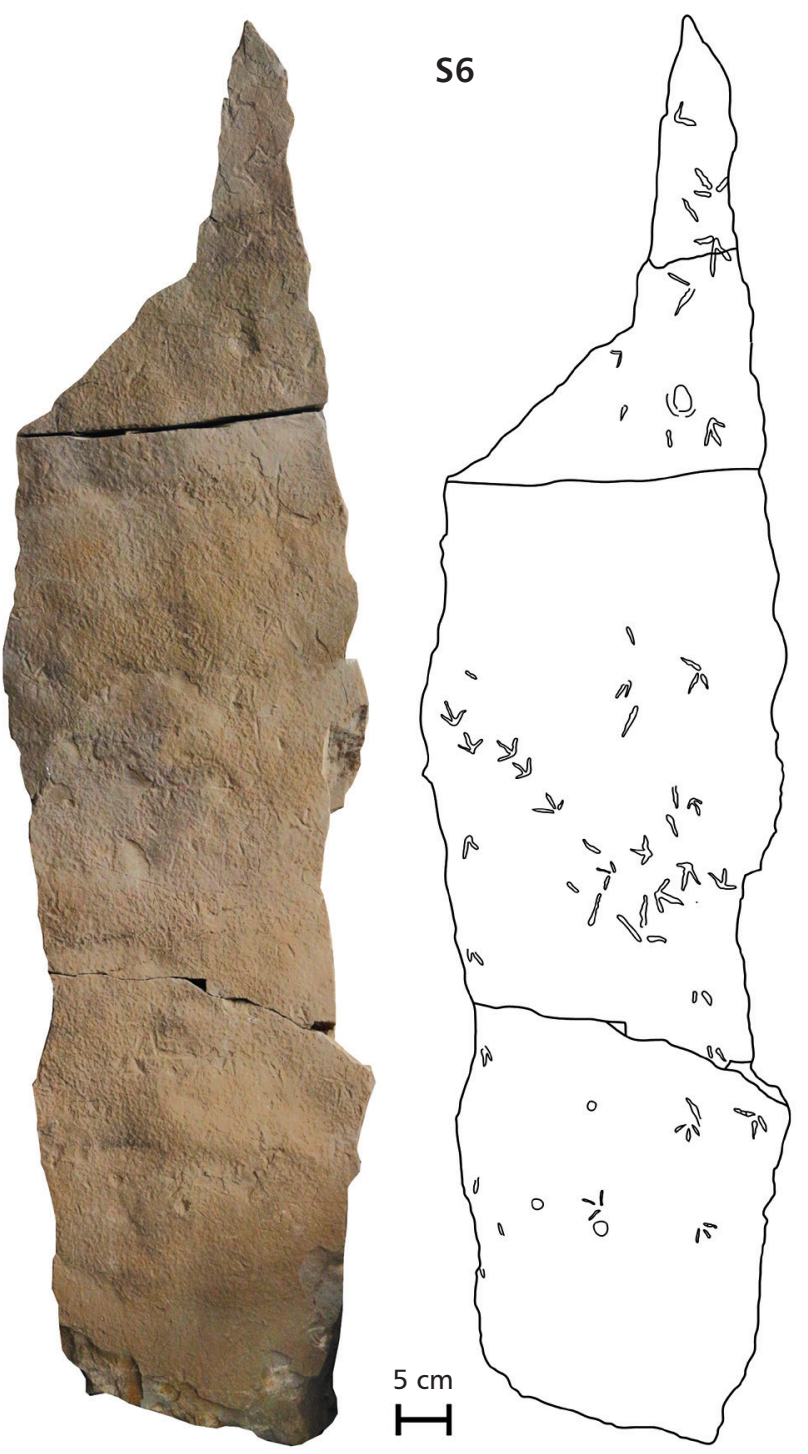

Figure 9. Poorly preserved Koreanaornis hamanensis as small sized bird footprints with slender digits (sample QGM-2888-S6). and $0.22-0.33$, respectively (Tab. 5). Although Persiavipes has the longest DLI $(2.4 \mathrm{~cm})$, its ratio of DLI/FL is equal to the mean of DLI/FL in the Ignotornidae. Ichnogenera of Ignotornidae have positive significant medial rotation towards the trackway midline. Hwangsanipes shows negative rotation (Tab. 5), and it may be the result of the arrangement of the footprints in a curved trackway (Yang et al. 1995, Fig. 5) or may be the result of measurement error by us on the figure 5 of Yang et al. (1995). The pace angulation is not constant in the ichnogenera and, of course, it is related to the speed of the bird.

In addition to morphological analysis of the ichnogenera of Ignotornidae, the morphology of Persiavipes is distinct from the other ichnogenera. Mehl (1931) mentioned a rudimentary web between digit I and II in the description of Ignotornis mcconnelli, this feature has been eliminated in the revised diagnosis by Kim et al. (2012). Persiavipes gulfi, however, shows a completely rounded posteriorly and isolated hallux imprint. $P$. gulfi differs from Ludicharadripodiscus edax Ellenberger, 1980 by the posteriorly rounded and well-developed digit I and high relief of the interdigital web. Sarjeantopodus semipalmatus (Lockley et al. 2004) is asymmetric semipalmate and has the interdigital web imprinted between digits III and IV.

Morphofamily Pecoripedidae Remeika et al., 1995

\section{Ichnogenus Pecoripeda Vialov, 1965}

\section{Pecoripeda gazella Vialov, 1965}

Figure 10

Material. - 16 footprints in the two large slabs (samples S7 and S8).

Description. - Hoofed footprints preserved as convex hyporelief (casts). Footprints have two imprints of hooves of slightly different size, and are overall heart-like in 


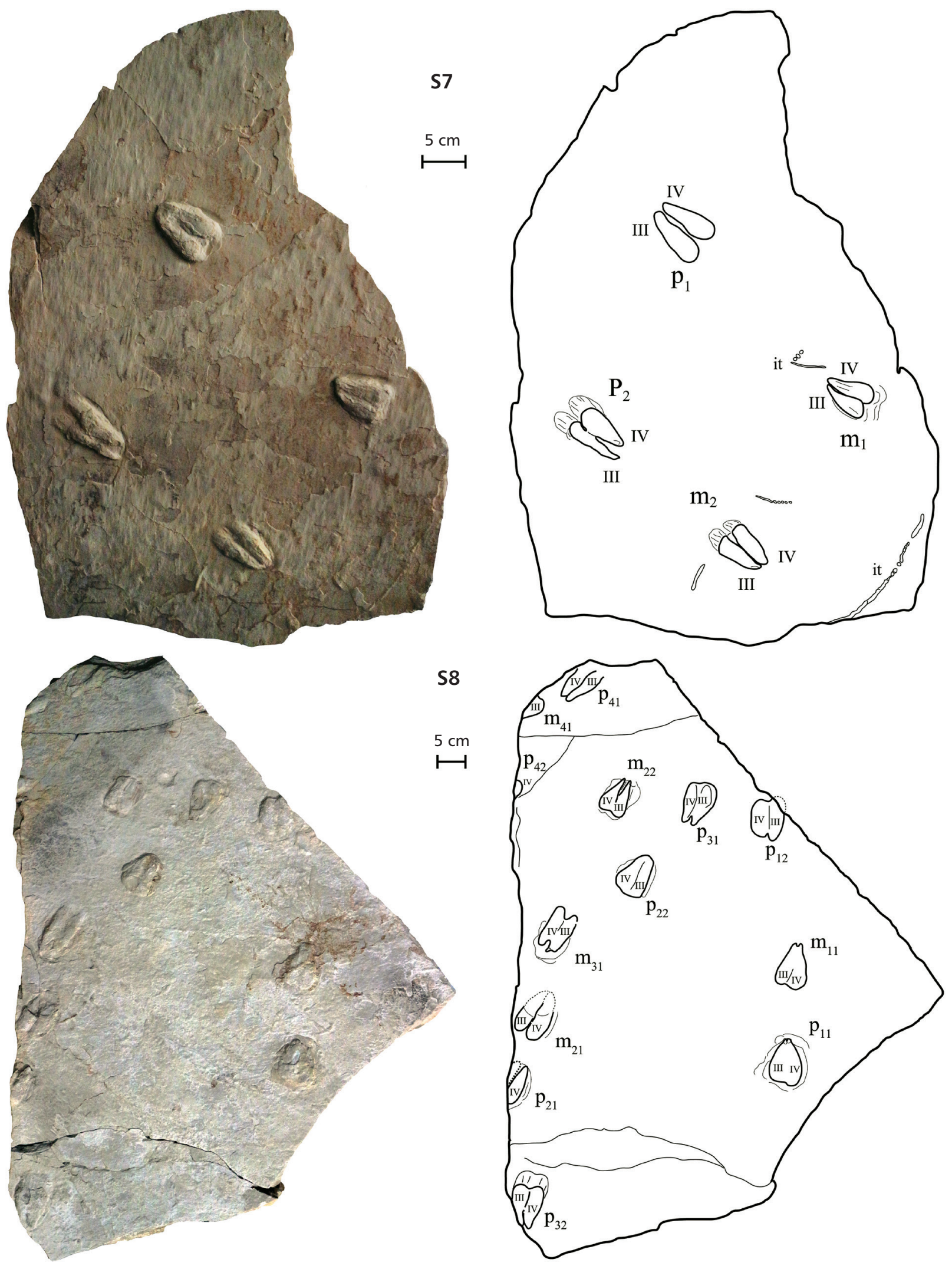

Figure 10. Pecoripeda gazella of studied slabs and coding of footprints. Abbreviations: $\mathrm{p}$ - pes; $\mathrm{m}$ - manus; it - invertebrate traces (samples QGM-2888-S7 and QGM-2888-S8). 
Table 6. Measurements on Pecoripeda gazella of studied footprints of the Agha Jari Formation (in centimeters).

\begin{tabular}{|c|c|c|c|c|c|c|c|c|c|c|c|c|}
\hline Sample & Trackway No. & Pes-Manus & FL & FW & FLIII & FWIII & FLIV & FWIV & $\frac{\mathrm{FL}}{\mathrm{FW}}$ & $\frac{\text { FLIII }}{\text { FWIII }}$ & $\frac{\text { FLIV }}{\text { FWIV }}$ & Pace \\
\hline \multirow{4}{*}{1} & \multirow{2}{*}{1} & $\mathrm{p}_{1}$ & 6.4 & 5.0 & 6.2 & 2.4 & 6.2 & 2.4 & 1.28 & 2.66 & 2.66 & \multirow{2}{*}{-} \\
\hline & & $\mathrm{m}_{1}$ & 5.2 & 3.7 & 5.0 & 2.0 & 5.2 & 2.0 & 1.4 & 2.5 & 2.6 & \\
\hline & \multirow{2}{*}{2} & $\mathrm{p}_{2}$ & 6.4 & 4.0 & 6.2 & 1.7 & 5.5 & 2.5 & 1.66 & 3.64 & 2.2 & \multirow{2}{*}{-} \\
\hline & & $\mathrm{m}_{2}$ & 5.4 & 4.0 & 5.0 & 2.0 & 5.0 & 1.8 & 1.35 & 2.5 & 2.77 & \\
\hline \multirow{14}{*}{2} & \multirow{3}{*}{1} & $\mathrm{p}_{11}$ & 8.0 & 5.5 & 7.3 & 2.7 & 8.0 & 3.0 & 1.45 & 2.7 & 2.66 & \multirow{3}{*}{42.7} \\
\hline & & $\mathrm{m}_{11}$ & 8.0 & 5.3 & 7.5 & 2.5 & 8.0 & 3.0 & 1.50 & 3 & 2.66 & \\
\hline & & $\mathrm{p}_{12}$ & 8.0 & 5.5 & 8.0 & 2.5 & 6.5 & 3.0 & 1.45 & 3.2 & 2.16 & \\
\hline & \multirow{4}{*}{2} & $\mathrm{p}_{21}$ & - & - & - & - & - & 2.5 & - & - & - & \multirow{4}{*}{40.5} \\
\hline & & $\mathrm{m}_{21}$ & 8.8 & 5.5 & 8.5 & 2.5 & 8.9 & 3.0 & 1.6 & 3.4 & 2.96 & \\
\hline & & $\mathrm{p}_{22}$ & 7.8 & 5.5 & 7.7 & 2.0 & 7.7 & 3.5 & 1.41 & 3.85 & 2.2 & \\
\hline & & $\mathrm{m}_{22}$ & 6.7 & 5.0 & 6.7 & 2.0 & 6.5 & 2.5 & 1.34 & 3.35 & 2.6 & \\
\hline & \multirow{3}{*}{3} & $\mathrm{p}_{31}$ & 8.0 & 5.3 & 7.8 & 3.3 & 7.0 & 2.0 & 1.50 & 2.36 & 3.5 & \multirow{3}{*}{75.0} \\
\hline & & $\mathrm{m}_{31}$ & 8.0 & 4.5 & 8.0 & 2.3 & 7.5 & 2.3 & 1.77 & 3.47 & 3.26 & \\
\hline & & $\mathrm{p}_{32}$ & 7.5 & 5.5 & 7.0 & 3.0 & 7.5 & 2.5 & 1.36 & 2.33 & 3.00 & \\
\hline & \multirow{3}{*}{4} & $\mathrm{p}_{41}$ & - & 4.2 & - & 2.3 & - & - & - & - & - & \multirow{3}{*}{-} \\
\hline & & $\mathrm{m}_{41}$ & - & - & - & 2.3 & - & - & - & - & - & \\
\hline & & $\mathrm{p}_{42}$ & - & - & - & - & - & - & - & - & - & \\
\hline & \multicolumn{2}{|l|}{ mean } & 7.2 & 4.8 & 6.2 & 2.3 & 6.8 & 2.5 & 1.46 & 2.99 & 2.71 & 52.7 \\
\hline
\end{tabular}

shape. Hooves contact each other posteriorly or along the interior margin of hooves. The tips of hooves are sharp or slightly rounded. Backward, a short slippage trace shows sliding of hooves, and sediment deformations are visible around the footprints. The average ratio of footprint length (FL) to footprint width (FW), FL/FW is 1.46 , and the inner hoof (digit III) is shorter and thinner than the outer one (digit IV) (Tab. 6).

Remarks. - We follow the diagnosis of the ichnogenus Pecoripeda and ichnospecies $P$. gazella by Sarjeant \& Langston (1994). Artiodactyl footprints comprise 15 valid ichnogenera (Sarjeant \& Langston 1994, McDonald et al. 2007, Abbassi et al. 2016), which were attributed to Cameloidea (Bijugopeda Sarjeant \& Reynolds, 1999; Camelipeda Vialov, 1984; Dizygopodium Sarjeant \& Reynolds, 1999; Gambapes Sarjeant \& Langston, 1994; Lamaichnum Aramayo \& Manera de Bianco, 1987; Megalamaichnum Aramayo \& Manera de Bianco, 1987; Paracamelichnum Pérez-Lorente et al., 2009); Cervoidea (Bifidipes Demathieu et al., 1984; Cervipeda Vialov, 1965; Megapecoripeda Kordos, 1985; Pecoripeda Vialov, 1965); Anoplotheriides (Anoplotheriipus Ellenberger, 1980; Diplartiopus Ellenberger, 1980), or Bovoides. These ichnogenera are classified in the morphofamily Pecoripedidae (Remeika et al. 1995). Numerous characters have been used in the ichnotaxonomic definition of artiodactyl footprints, and most of them have morphological bases. Sedimentological features of the substrate control the morphology of the footprints, but lack ichnotaxonomic value. For example, the variety of sedimentwater content and cohesiveness of fine-grained sediments caused different morphology in the footprints.

Scrivner \& Bottjer (1986) classified four different major preservational morphologies of artiodactyl footprints in the Copper Canyon Formation (Eocene), California. These categories range from wet sediments with an ovate, deep depression described as a "squelch mark" to the distorted morphology of partially upward pulled footprints; and the best-preserved footprints that were impressed in a moist or "slightly damp" substrate and, finally, shallow impressions (usually less than $1 \mathrm{~cm}$ deep) with poor resolution of morphological detail. The composition of sediment (e.g., clays behave very differently than sands) and water content of sediments are main factors in preservational morphologies of the footprints. These categories are visible in an observation of the tracks of a herd of sheep walking on fine-grained clayey sediment (Fig. 11), so that very shallow and poorly registered footprints are preserved in sediment of low plasticity. It is assumed that the type of sediment does not change in the observed area (about $50 \times 60 \mathrm{~cm}$ ) and only the water content of sediments was changed (increased from the lower to upper part in Fig. 11). 

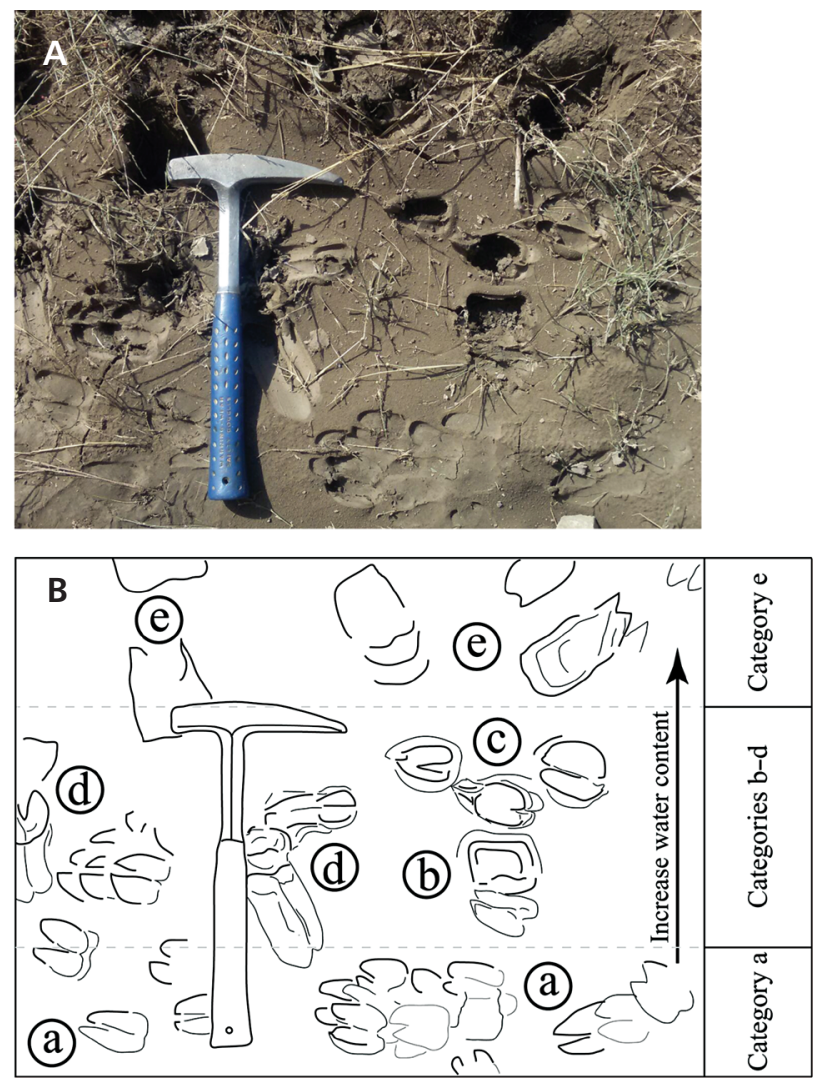

Figure 11. A variety of sheep foot imprints on fine-grained cohesive sediment with different water content (A) and sketched in five categories (B) (see text for details, photo by NA).

The potential of preservation of this kind of footprint is low, and the tips of toes are well preserved (Fig. 11Ba). An increase in the water content of sediments increases their plasticity, and the morphology of the footprints is distorted by the pastiness of the sediments. Hooves preserved as quadrangular, shallow depressions (Fig. 11Bb), deeply depressed footprints with strongly damaged rims around the footprints (Fig. 11Bc) and sliding imprints may occur (Fig. 11Bd). In the mostly wet sediments, footprints are impressed as very deep, oval-shaped traces (Fig. 11Be). Some of the named artiodactyl footprints are comparable to these kind preservations, for instance, Bifidipes aeolis Fornós et al., 2002, or Paracamelichnum jumillensis Pérez-Lorente et al., 2009, with a quadrangular shallow depression. Artiodactyl footprints of the Agha Jari Formation are well preserved with distinctive outlines; a few footprints show sliding imprints or slightly damaged rims of the footprints. These footprints are comparable to the mentioned categories $\mathrm{c}$ and d of $P$. gazella of the Agha Jari Formation, as they are large and elongate wedge shaped, and they differ from the P. amalphaea Vialov, 1965 (broad wedge-shaped and heart-shape outline), P. satyri (large, oval-triangular footprint), and $P$. diaboli (very wide and short tracks, with rounded to triangular outline).

\section{Results and Discussion}

Evaluation of the ichnodiversity is independent from the biodiversity, because ichnofossils are evidence for past behavior and may not reflect organismal diversity. Efficacy of environmental stress and stability, the ethological nature of trace-makers, taphonomy and stratinomy of trace fossils are main factors in the evaluation of ichnodiversity (Buatois \& Mángano 2013). The three components of biodiversity in the community include niche, habitat, and province, which are known as alpha, beta and gamma levels in the biodiversity (Whittaker 1972). Ichnodiversity, however, is discussable in different aspects, so that some trace fossils are restricted to distinctive facies, and some others are known as facies-crossing.

Based on the reported occurrences of tetrapod trace fossils (Tab. 1 and Fig. 3), we focus on the evaluation of the vertebrate ichnodiversity of the Mio-Pliocene in the Persian Gulf region and adjacent areas (Central Iran) (Fig. 3), which is equivalent to the beta level of biodiversity. The Central Iran region shows greater ichnodiversity of Cenozoic vertebrate footprints, and this is most likely influenced by the larger number of ichnological studies carried out in this area (Fig. 3), so there is a sampling bias, due to a higher collecting effort. These reports include Eocene sediments, Birjand area, eastern part of the Central Iran (Ataabadi \& Khazaee 2004), Oligocene sediments, Khaf area, northeastern part of the Central Iran (Abbassi et al. 2015), and late Miocene Upper Red Formation of the Eyvan-e key and Zanjan areas, northern and western parts of the Central Iran, respectively (Abbassi \& Shakeri 2005, Abbassi \& Amini 2008, Abbassi 2010, Alavi et al. 2016, Khoshyar et al. 2016). These reports show the ichnodiversity of the late Miocene Upper Red Formation is higher, which has a stratigraphic position equivalent to the Agha Jari Formation (and it is the equivalent stratigraphic unit in the Persian Gulf region, Fig. 3). The mammal tracks of the Upper Red Formation belong to carnivores, artiodactyls, and perissodactyls; bird footprints mostly are those of small to large shorebird tracks.

The Cenozoic terrestrial sediments of the Anatolian Plateau in the north Zagros Mountains may be other good candidates for vertebrate footprint discoveries. Oligocene artiodactyl and proboscidean tracks from the Sivas basin (Mesci et al. 2019) and Pleistocene human footprints from west Turkey (Ozansoy 1969) are terrestrial vertebrate footprints from the Anatolian Plateau.

The Mio-Pliocene track makers of the Persian Gulf region, however, are assignable to three classes, based on the track-makers and their size:

(1) Large-sized herbivorous mammals: this includes large mammal footprints from the late Miocene of the Baynunah Formation from Mleisa in the Abu Dhabi district, where 
more than 14 trackways are attributable to Proboscidea by the round shape and large size of the footprints, with very large trackway stride lengths. These trackways present direct evidence that proboscidean social structure in the late Miocene comprised both herding and solitary behavioral modes (Bibi et al. 2012). Ichnotaxonomically, these footprints are identifiable as the ichnogenus Proboscipeda Panin \& Avram, 1962. The Baynunah Formation contains very diverse vertebrate body fossils such as those of elephant, hippopotamus, horse, antelope, wolverine, hyaena, saber-tooth cat and primate (Hill \& Whybrow 1999, Gilbert et al. 2014). The body fossils of proboscideans of the Baynuneh Formation determined as Stegotetrabelodon Tassy, 1999. Omanitherium dhofarensis is known as the oldest proboscidean body fossils from the Arabian Peninsula from the early Oligocene of the Ashawq Formation, south Sultanate of Oman (Seiffert et al. 2012), and the Mukdadiya Formation of NE of Iraq has yielded mastodon fossils (Thomas et al. 1981). The Baynunah Formation, however, yields only proboscidean trackways in the Persian Gulf region. There are no other reports of proboscidean ichnofossils from other parts of the Persian Gulf region. Proboscidean tracks known from Central Iran include those from the late Miocene Upper Red Formation in the Zanjan area (personal observation). Proboscidean body fossils from the late Miocene of the Maragheh Formation (northwest Central Iran) include Choerolophodon pentelici and Deinotherium gigantissimum Bernor, 1986. Before the early Miocene, the Tethyan Seaway was, to a large extent, a natural barrier to land mammal migration between Africa and Eurasia; proboscideans are among the most prominent African immigrants, which arrived in Eurasia about 19 Ma ago via the Gomphotherium landbridge (Harzhauser et al. 2007). The Eocene tracksite of the Tarom Mountains in the western Alborz Mountains, north Iran, however, exhibits the oldest record of proboscidean footprints, and this indicates that proboscideans had reached the northern shore of Tethys by late Eocene time (Abbassi et al. 2017).

(2) Medium to small sized herbivorous mammals: this group includes artiodactyl footprints from both sides of the Persian Gulf: the Konar Takhteh and Chamchamal tracksites from the northern and northwestern Persian Gulf and the Musandam Peninsula tracksite from Oman in the southeastern Persian Gulf. Footprints of the Agha Jari Formation of Konar Takhteh, described herein, reach up to $8 \mathrm{~cm}$ in length and are attributable to Cervidae (Pecoripeda gazella). Artiodactyl footprints of the Mukdadiya Formation of Chamchamal differ from the Agha Jari or Musandam footprints (Karim et al. 2003). The Chamchamal tracksite includes two kinds of artiodactyl footprints; larger footprints with divergent toe imprints with a $7 \mathrm{~cm}$ length are similar to Bifidipes velox Demathieu et al., 1984, and smaller, heart-shaped footprints are $4-5 \mathrm{~cm}$ in length. These small footprints resemble Pecoripeda diaboli Vialov, 1965. The Oman artiodactyl footprints were not determined ichnotaxonomically, because the original tracks have not been found. On the other hand, the large size of epireliefs of the footprints (well over $25 \mathrm{~cm}$ in length) are preserved in poorly consolidated aeolian deposits, and the original size of the footprints may have been much smaller than the underlayer containing the footprints. However, considering the artiodactyl characteristics of these footprints, they were assigned to the ichnological order Artiodactipedida (Vialov 1966, Schulp et al. 2011).

Late Miocene artiodactyl and perissodactyl skeletal fossils in the adjacent areas of the Persian Gulf are: Hipparion, Suinae, Hippopotamus, Giraffidae, and Bovidae from the Baynunah Formation (Brunet \& Heintz 1983, Whybrow \& Clements 1999), Giraffidae and Bovidae from the Agha Jari Formation of Mesopotamia of Iraq (Al-Zubaidi \& Jan 2015), Hipparion from Mukdadiya (Thomas et al. 1981) and Suidae, Cervidae, Giraffidae, and Bovidae from the Maragheh Formation (Bernor 1986). Based on the sizes of the footprints, Suidae, Cervidae and Bovidae could be candidates as track-makers for artiodactyl footprints in the Persian Gulf region.

(3) Birds: bird footprints represent the first documents of vertebrate ichnites in the Persian Gulf region from the Lahbari Member of the Agha Jari Formation at Jabal Hamrin Mountain, western Iran (Lambrecht 1938, Abbassi et al. 2015). The Mio-Pliocene Agha Jari Formation of the Zagros Mountains and its equivalent Mukdadiya Formation in northeastern Iraq yield abundant large to small sized bird footprints. The large bird footprints of these formations at Jabal Hamrin Mountain on the IranIraq boundary (Lambrecht 1938) and in the Chamchamal area in northeastern Iraq (Karim et al. 2003) include tridactyl imprints with backward-directed, large hallux imprints. These footprints are Iranipeda abeli and were made by willet birds such as Ciconiiformes (Doyle et al. 2000).

The bird tracks of the Agha Jari Formation of Konar Takhteh, however, consist of limicoline, small-webbed and un-webbed bird footprints, named Koreanaornis hamanensis, and Persiavipes gulfi. There are no reports of bird footprints from southern parts of the Persian Gulf. Bird body fossils of Struthionidae and Ardeidae, however, have been reported from the Baynunah Formation of Abu Dhabi and the Agha Jari Formation of Mesopotamia (Whybrow \& Clements 1999).

The Miocene was a warm episode within the Neogene, contemporaneous with the closure of the Tethys seaway, 
which affected the paleobiogeography terrestrial biota. Mean annual temperature (MAT) of the early Miocene is estimated at about $16{ }^{\circ} \mathrm{C}$. The Middle Miocene was the warmest period in the whole Miocene, and MAT increased to $17{ }^{\circ} \mathrm{C}$ to $19{ }^{\circ} \mathrm{C}$. Climatic changes after the Miocene climatic optimum caused changes in plant assemblages and vegetation structure (Böhme 2003, Ivanov et al. 2007), which was important for herbivore distributions and caused the immigration of ecothermic vertebrates. Temperature and aridity of the late Miocene slightly decreased and displayed cycling in the warmer/cooler and humid/dryer conditions.

Climate changes during the Miocene-Pliocene interval, and the creation of new migration routes, are two main factors in the development of the new habitats and migration of vertebrates from the Arabian Peninsula to the Iranian plateau, and maybe vice versa. Ichnodiversity data of these regions, however, show increasing ichnodiversity from the interior of the Arabian Peninsula to Central Iran (Fig. 3). Based on current knowledge, it seems that the high ichnodiversity of Mio-Pliocene sediments of Central Iran (Upper Red Formation) relates to the high biodiversity of migrant track-makers after Mio-Pliocene tectonic and climate events, which created newly available habitat in Central Iran for immigrants from the Arabian Peninsula!? This hypothesis should be tested after the discovery of new tracksites in the Arabian Peninsula and the Persian Gulf region.

\section{Conclusions}

The Agha Jari Formation shows high potential for recording vertebrate footprints in the Zagros Mountains. Its mainly continental depositional environments created suitable substrates for the preservation of footprints. The Agha Jari Formation outcrops in the Konar Takhteh area, north Persian Gulf, record artiodactyl footprints assigned to Pecoripeda gazella and bird footprints assigned to Koreanaornis hamanensis and Persiavipes gulfi.

The Eocene Kashkan Formation, and the late MiocenePliocene Agha Jari, and Mukdadiya formations in the north of the Persian Gulf show higher ichnodiversity than the southern seaside of the Persian Gulf, so that only proboscideans and artiodactyl footprints have been previously reported from Cenozoic outcrops in these areas. The ichnodiversity of Cenozoic footprints in the Persian Gulf region increases from interior of parts of the Arabian Peninsula toward Central Iran. This suggests that the availability of new territories in Central Iran, after the closure of the Neotethys and the formation of the natural barrier of the Zagros Mountains, favored the increase of bio-and ichnodiveristy in the northern Persian Gulf.

\section{Acknowledgments}

The authors thank Spencer G. Lucas for his critical and valuable comments, and his help in editing of the manuscript in the English language. We thank M. Yazdi for his help. Aaron B. Camens and Veronica Krapovickas provided helpful reviews of the manuscript. We thank Zuzana Tasáryová for her help.

\section{References}

AbBassi, N. 2010. Vertebrate Footprints from the Miocene Upper Red Formation, Shokorchi Area, Zanjan Province, NW Iran. Ichnos 17(2),115-126. DOI 10.1080/10420941003659493

Abbassi, N. \& Amini, A. 2008. Ichnology of Miocene vertebrate footprints in the Upper Red Formation, Evan-e-key section, east Tehran, Iran. Geological Survey of Iran Scientific Quarterly Journal of Geoscience 67, 56-67.

Abbassi, N. \& ShaKeri, S. 2005. Miocene vertebrate footprints from the Upper Red Formation, Mushampa area, Zanjan province. Scientific Quarterly Journal of Geoscience 12(57), 76-89.

Abbassi, N., Lucas, S.G. \& ZaAre, G.R. 2015. First report of Oligocene vertebrate footprints from Iran. Palaeogeography, Palaeoclimatology, Palaeoecology 440, 78-89.

DOI 10.1016/j.palaeo.2015.08.039

Abbassi, N., Kundrát, M., Mirzaie AtaAbadi, M. \& Ahlberg, P.E. 2016. Avian ichnia and other vertebrate trace fossils from the Neogene Red Beds of Tarom valley in north-western Iran. Historical Biology 28(8),1075-1089. DOI 10.1080/08912963.2015.1104306

Abbassi, N., Alinasiri, S. \& Lucas, S.G. 2017. New localities of Late Eocene vertebrate footprints from the Tarom Mountains, Northwestern Iran. Historical Biology 29(7), 987-1006. DOI 10.1080/08912963.2016.1267162

Abbassi, N., Karim, K.H., Mohialdeen, I.M.J. \& Sharbazheri, K.M. 2020. Vertebrate footprints and a mammal mud-bath trace fossil (Laspichnia) from the Mukdadiya Formation (Late Miocene-Pliocene), Chamchamal Area, Kurdistan Region, Northeast Iraq. Ichnos, 1-12. DOI 10.1080/10420940.2020.1784156

Agard, P., Omrani, J., Jolivet, L. \& Mouthereau, F. 2005. Convergence history across Zagros (Iran): constraints from collisional and earlier deformation. International Journal of Earth Sciences 94(3), 401-419. DOI 10.1007/s00531-005-0481-4

Aghanabati, A. 2004. Geology of Iran. 586 pp. Geological Survey of Iran, Terhran, Iran.

Al-Zubaidi, A.A. \& JAN, S.K. 2015. Vertebrate Fossils in Fatha, Injana and Mukdadiya Formations in Iraq. Iraqi Journal of Science 56(3A),1983-1988.

ALAVI, M. 2004. Regional stratigraphy of the Zagros fold-thrust belt of Iran and its proforeland evolution. American Journal of Science 304(1), 1-20. DOI 10.2475/ajs.304.1.1

Alavi, Z., AbBassi, N. \& Zohdi, A. 2016. Ichnology of the seabird and shorebird footprints around the Miocene playa basins, an effort for paleoecology reconstruction of Upper 
Red Formation in the west of Zanjan province, 1-5. In $2^{\text {nd }}$ Symposium of Sedimentological Society of Iran, University of Ferdowsi, Mashhad, Iran.

Allen, M.B., Blanc, E.-P., Walker, R., Jackson, J., Talebian, M. \& Ghassemi, M.R. 2006. Contrasting styles of convergence in the Arabia-Eurasia collision: Why escape tectonics does not occur in Iran. Geological Society of America, Special Paper 409, 579-589. DOI 10.1130/2006.2409(26)

Anfinson, O.A., Lockley, M.G., Kim, S.H., Kim, K.S. \& Kim, J.Y. 2009. First report of the small bird track Koreanaornis from the Cretaceous of North America: implications for avian ichnotaxonomy and paleoecology. Cretaceous Research 30, 885-894. DOI 10.1016/j.cretres.2009.02.001

Aramayo, S.A. \& Manera de Bianco, T. 1987. Hallazgo de una icnofauna continental (Pleistoceno tardío) en la localidad de Pehuén-Có (Partido de Coronel Rosales), Provincia de Buenos Aires, Argentina, Parte II. Carnivora, Artiodactyla y Aves. $4^{\circ}$, 532-547. In Congreso Latinoamericano de Paleontología (La Paz, 1987), Resúmenes 1.

AtaAbadi, M.M. \& Khazaee, A.R. 2004. New Eocene mammal and bird footprints from Birjand area, eastern Iran. Ichnos 11(3-4), 363-370. DOI 10.1080/10420940490428724

Azuma, Y., Lu, J., Jin, X., Noda, Y., Shibata, M., Chen, R. \& ZHeNG, W. 2013. A bird footprint assemblage of early late Cretaceous age, Dongyang City, Zhejiang Province, China. Cretaceous Research 40, 3-9.

DOI 10.1016/j.cretres.2012.05.003

BAHRAMI, M. 2009. Lithofacies and sedimentary environments of Aghajari Formation in Dehsheikh Mountain, west of Shiraz, Iran. World Applied Science Journal 6(4), 464-473.

Belvedere, M., Dyke, G., Hadri, M. \& Ishigaki, S. 2011. The oldest evidence for birds in Northern Gondwana? Small tridactyl footprints from the Middle Jurassic of Msemrir (Morocco). Gondwana Research 19(2), 542-549.

DOI 10.1016/j.gr.2010.08.004

BERNOR, R.L. 1986. Mammalian biostratigraphy, geochronology, and zoogeographic relationships of the Late Miocene Maragheh fauna, Iran. Journal of Vertebrate Paleontology 6(1),76-95. DOI 10.1080/02724634.1986.10011600

Bibi, F., Kraatz, B., Craig, N., Beech, M., Schuster, M. \& HiLl, A. 2012. Early evidence for complex social structure in Proboscidea from a late Miocene trackway site in the United Arab Emirates. Biology Letters 8(4), 670-673.

DOI 10.1098/rsbl.2011.1185

BöHME, M. 2003. The Miocene climatic optimum: evidence from ectothermic vertebrates of Central Europe. Palaeogeography, Palaeoclimatology, Palaeoecology 195(3-4), 389-401. DOI 10.1016/S0031-0182(03)00367-5

BRunet, M. \& Heintz, E. 1983. Interpretation paleoecologique et relations biogeographiques de la faune de vertebrees du Miocene Superieur D'Injana, Irak. Palaeogeography, Palaeoclimatology, Palaeoecology 44(3-4), 283-293. DOI 10.1016/0031-0182(83)90107-4

Buatois, L.A. \& Mángano, M.G. 2013. Ichnodiversity and ichnodisparity: significance and caveats. Lethaia 46(3), 281-292. DOI 10.1111/let.12018

Burberry, C.M. 2015. The effect of Basement fault reactivation on the Triassic-recent geology of Kurdistan, north Iraq. Journal of Petroleum Geology 38(1), 37-58.

DOI 10.1111/jpg.12597

Camens, A.B. \& Worthy, T.H. 2019. Pliocene avian footprints from the Lake Eyre Basin, South Australia, Journal of Vertebrate Paleontology 39(4), e1676764.

DOI 10.1080/02724634.2019.1676764

De Valais, S. \& Melchor, R.N. 2008. Ichnotaxonomy of bird-like footprints: an example from the Late Triassic-Early Jurassic of northwest Argentina. Journal of Vertebrate Paleontology 28(1), 145-159.

DOI 10.1671/0272-4634(2008)28[145:IOBFAE]2.0.CO;2

Demathieu, G., Ginsburg, L., Guerin, C. \& Truc, G. 1984. Étude paléontologique, ichnologique et paléoécologique du gisement oligocène de Saignon (Bassin d'Apt, Vaucluse). Bulletin du Muséum national d'histoire naturelle. Section $C$, Sciences de la terre, paléontologie, géologie, minéralogie 6(2), 153-183.

Doyle, P., Wood, J.L. \& George, G.T. 2000. The shorebird ichnofacies: an example from the Miocene of southern Spain. Geological Magazine 137(5), 517-536. DOI 10.1017/S0016756800004490

Ellenberger, P. 1980. Sur les empreintes de pas de gros mammiféres de l'Eocène supérieur de Garrigues-Ste-Eulalie (Gard). Paleovertebrata, Mémoire Jubilé R. Lavocat, 37-78.

Falkingham, P.L. 2012. Acquisition of high resolution threedimensional models using free, open-source, photogrammetric software. Palaeontologia Electronica 15(1), 1-15. DOI 10.26879/264

Falkingham, P.L., Bates, K.T., Avanzini, M., Bennett, M., Bordy, E.M., Breithaupt, B.H., Castanera, D., Citton, P., Díaz-Martínez, I. \& Farlow, J.O. 2018. A standard protocol for documenting modern and fossil ichnological data. Palaeontology 61(4), 469-480. DOI 10.1111/pala.12373

Fornós, J.J., Bromley, R.G., Clemmensen, L.B. \& RodriguezPereA, A. 2002. Tracks and trackways of Myotragus balearicus Bate (Artiodactyla, Caprinae) in Pleistocene aeolianites from Mallorca (Balearic Islands, Western Mediterranean). Palaeogeography, Palaeoclimatology, Palaeoecology 180(4), 277-313. DOI 10.1016/S0031-0182(01)00431-X

Ghazban, F. \& Motiei, H. 2009. Petroleum Geology of the Persian Gulf. 707 pp. Tehran University Press, Tehran, Iran.

Gilbert, C.C., Bibi, F., Hill, A. \& Beech, M.J. 2014. Early guenon from the late Miocene Baynunah Formation, Abu Dhabi, with implications for cercopithecoid biogeography and evolution. Proceedings of the National Academy of Sciences 111(28), art. 201323888. DOI 10.1073/pnas.1323888111

Glennie, K., Boeuf, M., Clarke, M.H., Moody-Stuart, M., PilaAr, W. \& Reinhardt, B. 1973. Late Cretaceous nappes in Oman Mountains and their geologic evolution. $A A P G$ Bulletin 57(1), 5-27.

DOI 10.1306/819A4240-16C5-11D7-8645000102C1865D

Harington, C.R., Foster, H., Holmes, R. \& Currie, P.J. 2005. Photographic catalogue of trackways in the Canadian Museum of Nature. Syllogeus 74, 1-151.

Harzhauser, M., Kroh, A., Mandic, O., Piller, W.E., Göhlich, U., 
Reuter, M. \& Berning, B. 2007. Biogeographic responses to geodynamics: a key study all around the Oligo-Miocene Tethyan Seaway. Zoologischer Anzeiger - A Journal of Comparative Zoology 246(4), 241-256.

DOI 10.1016/j.jcz.2007.05.001

Higgs, W. Kirkham, A., Evans, G. \& Hull, D. 2003. A Late Miocene proboscidean trackway from western Abu Dhabi. Tribulus 13, 3-8.

Hill, A. \& Whybrow, J. 1999. Summary and overview of the Baynunah Fauna, Emirate of Abu Dhabi, and its context, 7-14. In Whybrow, P. \& Hill, A. (eds) Fossil Vertebrates of Arabia, with Emphasis on the Late Miocene Faunas, Geology, and Palaeoenvironments of the Emirate of Abu Dhabi, United Arab Emirates. Yale University Press, New Haven, Connecticut.

Hopkins, D.M. 1959. Cenozoic History of the Bering Land Bridge. Science 129(3362), 1519-1528.

DOI 10.1126/science.129.3362.1519

Ivanov, D.A., Ashraf, A.R. \& Mosbrugger, V. 2007. Late Oligocene and Miocene climate and vegetation in the Eastern Paratethys area (northeast Bulgaria), based on pollen data. Palaeogeography, Palaeoclimatology, Palaeoecology 255(3-4), 342-360. DOI 10.1016/j.palaeo.2007.08.003

JAMES, G. \& WYND, J. 1965. Stratigraphic nomenclature of Iranian oil consortium agreement area. AAPG Bulletin 49(12), 2182-2245.

DOI 10.1306/A663388A-16C0-11D7-8645000102C1865D

JASSIM, S. \& BuDAY, T. 2006. Latest Eocene-Recent Megasequence AP11, 169-184. In JASsim, S.Z. \& GoFF, J.C. (eds) Geology of Iraq. Dolin, Prague and Moravian Museum.

Karim, K.H., Ismael, K.M. \& Mohyaddin, I.M.J. 2003. New discovery of some vertebrate footprintss in Mukdadiya Formation from Chamchamal area, NE Iraq. Journal of Iraqi Geological Society 34(1), 1-10.

Khoshyar, M., Abbassi, N. \& Zohdi, A. 2016. Ichnology of the Gruiformes coastal bird footprint from Upper Red Formation (Miocene), Hesar region, west of the Zanjan Province, 1-8. In $35^{\text {th }}$ National Geosciences Congress. Geological Survey of Iran (GSI), Tehran, Iran.

KIM, B.K. 1969. A study of several sole marks in the Haman Formation. Journal of the Geological Society of Korea 5, 243-258.

KIm, J.Y., KIm, S.H., Kim, K.S. \& Lockley, M.G. 2006. The oldest record of webbed bird and pterosaur tracks from South Korea (Cretaceous Haman Formation, Changseon and Sinsu Islands): more evidence of high avian diversity in East Asia. Cretaceous Research 27(1), 56-69.

DOI 10.1016/j.cretres.2005.10.005

KIM, J.Y., Lockley, M.G., Seo, S.J., Kim, K.S., KIm, S.H. \& BAEK, K.S. 2012. A paradise of Mesozoic birds: The world's richest and most diverse Cretaceous bird track assemblage from the Early Cretaceous Haman Formation of the Gajin tracksite, Jinju, Korea. Ichnos 19(1-2), 28-42.

DOI 10.1080/10420940.2012.660414

Kıм, J.Y., Кıм, M.K., Он, M.S. \& LeE, C.Z. 2013. A new semipalmate bird track, Gyeongsangornipes lockleyi ichnogen. et ichnosp. nov., and Koreanornis from the Early Cretaceous
Jindong Formation of Gosong County, southern coast of Korea. Ichnos 20, 72-80. DOI 10.1080/10420940.2013.787071

Koop, W. \& Stoneley, R. 1982. Subsidence history of the Middle East Zagros basin, Permian to recent. Philosophical Transactions of the Royal Society of London A 305(1489), 149-168. DOI 10.1098/rsta.1982.0031

KoRDOS, L. 1985. Lábnyomok az ipolytarnóci alsó-Miocén korú homokköben. Geologica Hungarica 46 (Palaeontologica 1983), 259-415.

Lambrecht, K. 1938. Urmiornis abeli n. sp., eine Pliozäne Vogelfährte aus Persien. Palaeobiologica 6(2), 242-245.

Leonard, G. 1987. Glossary and Manual of Tetrapod Footprint Palaeoichnology. 75 pp. Departamento Nacionalde Producao Mineral, Brasilia.

Lockley, M.G. \& Harris, J.D. 2010. On the Trail of Early Birds: a Review of the Fossil Footprint Record of Avian Morphological and Behavioral Evolution, 1-63. In UlRICH, P.K. ET AL. (eds) Trends in Ornithology Research. Nova Science Publishers.

Lockley, M.G., Yang, S.Y., Matsukana, M., Fleming, F. \& Lim, S.K. 1992. The track record of Mesozoic birds: Evidence and implications. Philosophical Transactions of the Royal Society of London 336, 113-134. DOI 10.1098/rstb.1992.0051

Lockley, M.G., Nadon, G. \& Currie, P.J. 2004. A diverse dinosaur-bird footprint assemblage from the Lance Formation, Upper Cretaceous, eastern Wyoming: implications for ichnotaxonomy. Ichnos 11(3-4), 229-249. DOI 10.1080/10420940490428625

Lockley, M.G., Houck, K., YanG, S.Y., Matsukawa, M. \& Lim, S.K. 2006. Dinosaur-dominated footprint assemblages from the Cretaceous Jindong Formation, Hallyo Haesang National Park area, Goseong County, South Korea: Evidence and implications. Cretaceous Research 27, 70-101.

DOI 10.1016/j.cretres.2005.10.010

Lockley, M.G., Kim, J.Y., Kim, K.S., Kim, S.H., MatsukaWa, M., LI, R., LI, J. \& YANG, S.Y. 2008. MinisauripusdThe track of a diminutive dinosaur from the Cretaceous of China and South Korea: Implications for stratigraphic correlation and theropod foot morphodynamics. Cretaceous Research 29, 115-130. DOI 10.1016/j.cretres.2007.04.003

Lockley, M.G., Lim, J.D., Kim, J.Y., Kim, K.S., Huh, M. \& Hwang, K.G. 2012. Tracking Korea's early birds: a review of Cretaceous avian ichnology and its implications for evolution and behavior. Ichnos 19, 17-27.

DOI 10.1080/10420940.2012.660409

McDonald, H.G., White, R.S., Lockley, M.G. \& Mustoe, G. 2007. An indexed bibliography of Cenozoic vertebrate tracks, 275-302. In Lucas, S.G., Spielmann, J. \& Lockley, M.G. (eds) Cenozoic Vertebrate Tracks and Traces.Volume 42. New Mexico Museum of Natural History and Science.

Mesci, B.L., Erkman, A.C. \& Özkurt, Ş.Ö. 2019. Primary report of first documentation of mammal footprints from the late Oligocene in the Sivas Basin, Turkey. Turkish Journal of Earth Sciences 28(6), 822-833.

MerL, M.G. 1931. Additions to the vertebrate record of the Dakota Sandstone. American Journal of Science 125, 441-452. DOI 10.2475/ajs.s5-21.125.441 
Mohajuel, M. \& Fergusson, C. 2014. Jurassic to Cenozoic tectonics of the Zagros Orogen in northwestern Iran. International Geology Review 56(3), 263-287.

DOI 10.1080/00206814.2013.853919

Motiei, H. 1993. Geology of Iran-Zagros Stratigraphy. 536 pp. Geological Survey of Iran, Tehran, Iran.

Ozansoy, F. 1969. Pleistocene fossil human footprints in Turkey. Maden Tetkik ve Arama Dergisi 72(72), 144-152.

Panin, N. \& Avram, E. 1962. Noi urme de vertebrate in Miocenul Subcarpatilor Rominesti. Studii si Cercetari de Geologie 7 , 455-484.

Payros, A., Astibia, H., Cearreta, A., Pereda-Suberbiola, X., Murelaga, X. \& Badiola, A. 2000. The Upper Eocene South Pyrenean Coastal deposits (Liedena sandstone, navarre): Sedimentary facies, benthic formanifera and avian ichnology. Facies 42(1), 107-131. DOI 10.1007/BF02562569

Pérez-Lorente, F., Herrero, C., Herrero, E. \& Montoya, P. 2009. Paracamelichnum jumillensis n. ichnogen. n. ichnosp., Upper Miocene Camelidae ichnites from the Hoya de la Sima site (Murcia, Spain). Ichnos 16(3), 208-219.

DOI 10.1080/10420940802686087

Pirouz, M., Simpson, G., Bahroudi, A. \& Azhdari, A. 2011. Neogene sediments and modern depositional environments of the Zagros foreland basin system. Geological Magazine 148(5-6), 838-853. DOI 10.1017/S0016756811000392

Purser, B.H. \& SEIBold, E. 1973. The principal environmental factors influencing Holocene sedimentation and diagenesis in the Persian Gulf, 1-9. In Purser, BH. (ed.) The Persian Gulf. Springer. DOI 10.1007/978-3-642-65545-6_1

Remeika, P., Jefferson, G.T. \& Murray, L.K. 1995. Fossil vertebrate faunal list for the Vallecito-Fish Creek and Borrego-San Felipe Basins,Anza-Borrego Desert State Park and vicinity, California, 82-93. In RemeikA, P. \& Sturz, A. (eds) Paleontology and Geology of the Western Salton Trough Detachment, Anza-Borrego Desert State Park, California: San Diego, U.S.A. San Diego Association of Geologists, Field Trip Guidebook I.

Sahraeyan, M. \& Bahrami, M. 2012. Geochemistry of sandstones from the Aghajari Formation, Folded Zagros Zone, southwestern Iran: implication for paleoweathering condition, provenance, and tectonic setting. International Journal of Basic and Applied Sciences 1(4), 390-407.

DOI 10.14419/ijbas.v1i4.244

Sarjeant, W.A.S. \& Langston, J.W. 1994. Vertebrate footprints and invertebrate traces from the Cadronian (Late Eocene) of Trans-Pecos Texas. Texas Memorial Museum Bulletin 36, 1-86.

Sarjeant, W.A. S. \& Reynolds, R.E. 1999. Camelid and horse footprints from the Miocene of California and Nevada. San Bernardino County Museum Association Quarterly 46, 3-20.

SARJEAnt, W.A.S. \& REYnolds, R.E. 2001. Bird footprints from the Miocene of California, 21-40. In REYNOLDS, R.E. (ed.) The Changing Face of the East Mojave Desert: Abstracts from the 2001 Desert Symposium: California State University, Desert Studies Consortium.

Schulp, A S., Belvedere, M., Nasir, S. \& Wheeler, M. 2011. An Artiodactyl Tracksite at Musandam Peninsula, Sultanate of Oman. Ichnos 18(4), 192-196.

DOI 10.1080/10420940.2011.632659
Scrivner, P.J. \& BottJer, D.J. 1986. Neogene avian and mammalian tracks from Death Valley National Monument, California: their context, classification and preservation. Palaeogeography, Palaeoclimatology, Palaeoecology 57(2-4), 285-331. DOI 10.1016/0031-0182(86)90017-9

Seiffert, E.R., Nasir, S., Al-Harthy, A., GroenKe, J.R., Krattz, B.P., Stevens, N.J. \& Al-Sayigh, A.R. 2012. Diversity in the later Paleogene proboscidean radiation: a small barytheriid from the Oligocene of Dhofar Governorate, Sultanate of Oman. Naturwissenschaften 99(2), 133-141. DOI 10.1007/s00114-011-0878-9

Sepehr, M. \& Cosgrove, J. 2004. Structural framework of the Zagros fold-thrust belt, Iran. Marine and Petroleum Geology 21(7), 829-843. DOI 10.1016/j.marpetgeo.2003.07.006

Setudehnia, A. \& Perry, O.B. 1967. Musian (Jabal Hamrin) geological compilation map. Drawing No. 25469 W. National Iranian Oil Company, Tehran, Iran.

Sherkati, S. \& Letouzey, J. 2004. Variation of structural style and basin evolution in the central Zagros (Izeh zone and Dezful Embayment), Iran. Marine and Petroleum Geology 21(5), 535-554. DOI 10.1016/j.marpetgeo.2004.01.007

Searle, M., James, N., Calon, T. \& Smewing, J. 1983. Sedimentological and structural evolution of the Arabian continental margin in the Musandam Mountains and Dibba zone, United Arab Emirates. Geological Society of America Bulletin 94(12), 1381-1400.

DOI 10.1130/0016-7606(1983)94<1381:SASEOT>2.0.CO;2

Steininger, F.F., Rabeder, G. \& RöGl, F. 1985. Land mammal distribution in the Mediterranean Neogene: a consequence of geokinematic and climatic events, 559-571. In STANLEY, D.J. \& Wezel, F.C. (eds) Geological evolution of the Mediterranean Basin. Springer.

DOI 10.1007/978-1-4613-8572-1_26

Stöcklin, J. 1968. Structural history and tectonics of Iran: a review. AAPG Bulletin 52(7), 1229-1258. DOI 10.1306/5D25C4A5-16C1-11D7-8645000102C1865D

STÖCKLIN, J. 1977. Structural correlation of the Alpine ranges between Iran and Central Asia. Memoire Hors-Serve 8, 333-353.

Stöcklin, J. \& Setudehnia, A. 1991. Stratigraphic Lexicon of Iran. Geological Survey of Iran Report 18, 1-376.

TAssy, P. 1999. Miocene elephantids (Mammalia) from the Emirate of Abu Dhabi, United Arab Emirates: palaeobiogeographic implications, 209-233. In WhyBrow, P.J. \& Hill, A. (eds) Fossil Vertebrates of Arabia. Yale University Press, New Haven.

TChernov, E. 1992. The Afro-Arabian component in the Levantine mammalian fauna-a short biogeographical review. Israel Journal of Zoology 38(3-4), 155-192.

Thomas, H., Behnam, H. \& Ligabue, G. 1981. New formation, discoveries of vertebrate fossils in the Bakhtiari Formation, Injana area, Himrin, South Iraq. Journal of Geological Society of Iraq 14, 43-54.

Vialov, O. S. 1965. Stratigrafiya neogenovix molass Predcarpatskogo progiba. 191 pp. Naukova Dumka, Kiev.

VIALov, O.S. 1966. Sledy zhiznedeyatelnosti organizmov $i$ ikh paleontologicheskoe znacheniye. 219 pp. Naukova Dumka, Kiev. 
VIALOV, O.S. 1984. Sledy verblyudov i drugikh pozvonochnykh v pliotsene Zapadnoy Turkmenii, 18-21. In KruchinInA, N.V. (ed.) Sledy zhizni i dinamika sredy $v$ drevnikh biotopakh. Tezisy dokladov XXX sessii Vsesoyuznogo paleontologicheskogo obshchestva 30.

VIALOV, O.S. 1989. Pliocene bird tracks from Iran assigned to the genus Urmiornis. Paleontological Journal 23(3), 119-121.

VRBA, E.S. 1992. Mammals as a key to evolutionary theory. Journal of Mammalogy 73(1), 1-28. DOI 10.2307/1381862

WhitTAKer, R.H. 1972. Evolution and measurement of species diversity. Taxon 21(2-3), 213-251. DOI 10.2307/1218190

WhyBrow, P.J. 1988. New stratotype; The Baynunah Formation (Late Miocene), United Arab Emirates: Lithology and palaeontology. Newsletters on Stratigraphy 21(1), 1-9. DOI 10.1127/nos/21/1989/1

Whybrow, P. \& Clements, D. 1999. Arabian Tertiary fauna, flora, and localities, 460-472. In Whybrow, P.J. \& Hill, A. (eds) Fossil Vertebrates of Arabia. Yale University Press, New Haven.

Whybrow, P., Friend, P., Ditchfield, P. \& Bristow, C. 1999. Local stratigraphy of the Neogene outcrops of the coastal area: western region, Emirate of Abu Dhabi, United Arab Emirates, 28-37. In Whybrow, P.J. \& Hill, A. (eds) Fossil Vertebrates of Arabia. Yale University Press, New Haven.

Xing, L.D., Harris, J.D., Jia, C.K., Luo, Z.J., Wang, S.N. \& AN, J.F. 2011. Early Cretaceous bird-dominated and dinosaur footprint assemblages from the Northwestern Margin of the Junggar Basin, Xinjiang, China. Palaeoworld 20, 308-321. DOI 10.1016/j.palwor.2011.01.001

Xing, L.D., Buckley, L.G., Lockley, M.G., Zhang, J.P., Marty, D., Wang, Y., Li, J.J., McCrea, R.T. \& Peng, C. 2016. A new bird track, Koreanaornis lii ichnosp. Nov., from the lower Cretaceous Hekou Group in the LanzhouMinhe Basin, Gansu, Northwest China, and implications for early Cretaceous avian diversity. Cretaceous Research 66, 141-154. DOI 10.1016/j.cretres.2016.06.005

XInG, L.D., Hu, Y.C., Huang, J.D., He, Q., Lockley, M.G., Burns, M.E. \& FAng, J. 2018. A redescription of the ichnospecies Koreanaornis anhuiensis (Aves) from the Lower Cretaceous Qiuzhuang Formation at Mingguang city, Anhui Province, China. Journal of Palaeogeography 7(1), 58-65. DOI 10.1016/j.jop.2017.10.003

Yang, S.Y., Lockley, M.G., Greben, R., Erickson, B.R. \& Lim, S.K. 1995. Flamingo and duck-like bird tracks from the Late Cretaceous and early Tertiary: evidence and implications. Ichnos 4, 21-34. DOI 10.1080/10420949509380111

Yazdi, M., Bahrami, A., Abbasi, P., Sadeghi, R. \& Vega, F.J. 2013. Miocene brachyuran Crustacea from Konar-Takhteh and Ahram sections, southwestern Iran. Boletín de la Sociedad Geológica Mexicana 65(2), 225-233.

DOI 10.18268/BSGM2013v65n2a4

Yousefi Yeganeh, B., Feiznia, S. \& AbBassi, N. 2011. Sedimentary facies, architectural elements and trace fossils of Kashkan Formation, folded Zagros zone in SW Iran. Journal of Sciences, Islamic Republic of Iran 22(3), 239-255.

Zhen, S., Li, J., Chen, W. \& Zhu, S. 1995. Dinosaur and bird footprints from the Lower Cretaceous of Emei County, Sichuan. Memoirs of the Beijing Natural History Museum 54, 105-120.

Ziegler, M.A. 2001. Late Permian to Holocene paleofacies evolution of the Arabian Plate and its hydrocarbon occurrences. GeoArabia 6(3), 445-504.

Zonneveld, J.-P., Zaim, Y., Rizal, Y., Ciochon, R., Bettis III, E. \& Gunnell, G. 2012. Ichnological constraints on the depositional environment of the Sawahlunto Formation, Kandi, northwest Ombilin Basin, west Sumatra, Indonesia. Journal of Asian Earth Sciences 45, 106-113.

DOI 10.1016/j.jseaes.2011.06.017 